\title{
Why Agencies Act: A Reassessment of the Ossification Critique of Judicial Review
}

\author{
MARK SEIDENFELD*
}

\section{INTRODUCTION-AGENCY DECISIONS TO ACT IN RESPONSE TO A PERCEIVED PROBLEM}

Agencies often are given discretion about whether and when to address a problem. The modern administrative state is characterized by broad delegations of policy matters to agencies under statutes that merely identify the area within which the agency is to exercise power. Statutes frequently fail to direct an agency to focus on particular problems within the ambit of an agency's regulatory authority and rarely demand that agencies actually regulate particular conduct of those whom the statute potentially subjects to agency jurisdiction. ${ }^{1}$

Flexibility, which is meant to allow an agency to react to changing circumstances more quickly than can Congress, is one justification for granting agencies such broad discretion. Responding to a problem can demand the collection and analysis of vast amounts of information to try to determine the cause of the problem and the likely impacts of any solution. Arguably, agencies have expertise, enjoy relationships with the stakeholders involved in any controversy within the agency's authority, and operate in accordance with fairly simple rulemaking procedures, all of which facilitate such collection and analysis of data. In addition, agencies are divorced, at least to some extent, from direct political pressures, and because their actions are national in scope, often have less need to placate special interest constituents than do members of Congress.

Over the past two decades, administrative law scholars have identified hard look judicial review of agency action under the arbitrary and capricious

* Patricia A. Dore Professor of Administrative Law, The Florida State University College of Law. I would like to thank Greg Mitchell, Barry Weingast, Roger Noll, Anne Joseph O'Connell, Jim Rossi, Peter Strauss, Matt Stephenson, Dan Rodriguez, Jerry Mashaw, Ron Levin, Margo Schlanger, Manuel Utset, the faculties of the Washington University, Southern Methodist University, and Florida State University law schools, as well as the participants in the conference on "Administrative Law and Process in the U.S. and Abroad: Cross-Disciplinary Perspectives," University of San Diego School of Law and the University of California San Diego Department of Political Science and Graduate School of International Relations and Pacific Studies for comments on presentations and earlier drafts of this article.

${ }^{1}$ In this article, I use the terms "regulation" and "action" to refer to any change in policy adopted by an agency, including adopting a policy in the face of regulatory vacuum, amending existing policy and repealing existing policy. 
clause of the Administrative Procedure Act (APA) as one of, if not the major, impediment to regulatory flexibility. ${ }^{2}$ Such scholars contend that review, as currently implemented by the courts, places so many analytic burdens and such uncertainty on agency policymaking that it discourages agencies from acting even when regulatory changes are needed. This position is reflected in the commonly stated adage that judicial review causes ossification of the rulemaking process. ${ }^{3}$ In essence, these critics argue that judicial review raises the costs of agency adoption of new policy and thereby discourages such action.

Elsewhere, I have defended hard look review by arguing that such review is structured to encourage agencies to be more careful when setting policy, and to take into account a broad array of stakeholder vantage points regarding the underlying problems and the likely impact of policies meant to alleviate those problems. ${ }^{4} \mathrm{I}$ argued that review encourages more careful action, the benefits of which counterbalance the costs imposed by review. Previously, however, I conceded that to the extent review dissuaded agency action it imposed a cost on society.

In this Article, I want to revisit that concession for two reasons. First, judicial review imposes costs on an agency, but regulatory action provides benefits and imposes costs on society as a whole that may not correlate with the costs the agency sees. In essence, the cost that the agency bears in order to act is the price of action, and because this price does not reflect the marginal cost to society and the benefits that the agency derives from action do not correspond to the social benefits from that action, the price can give the agency an improper signal about whether to act. To the extent that costs imposed on the agency by judicial review of an action inversely correlate with the net societal benefit flowing from that action, judicial review can help align the incentives for agency action with that net benefit.

Second, judicial review is not the only influence on agency policy setting. Numerous factors influence agency decisions whether and when to act. These include incentives that affect the propensity of individuals within an agency to act, psychological influences that also affect that propensity, and agency decision-making structures and processes that can moderate

${ }^{2}$ See, e.g., Jerry L. Mashaw, Improving the Environment of Agency Rulemaking: An Essay on Management, Games, and Accountability, 57 LAW \& CONTEMP. ProBS., 185, 200-04, 229-30 (1994); R. Shep Melnick, Administrative Law and Bureaucratic Reality, 44 ADMIN. L. REv. 245, 247 (1992); Richard J. Pierce, Jr., Two Problems in Administrative Law: Political Polarity on the District of Columbia Circuit and Judicial Deterrence of Agency Rulemaking, 1988 DUKE L.J. 300, 300-03, 308-13.

${ }^{3}$ For prominent examples of this literature, see sources collected in Mark Seidenfeld, Demystifying Deossification: Rethinking Recent Proposals to Modify Judicial Review of Notice and Comment Rulemaking, 75 TEX. L. REV. 483, 483 n.1 (1997).

${ }^{4}$ See generally id. at 489-90. 
individual decision makers' influence on agency policy priorities, and thereby change the likelihood that the agency, as an institution, decides to address a problem. In an ideal world, agencies would respond to a problem only when the outcome that would result from taking action is preferable (however the polity's preference is defined) to the outcome that would result from no action..$^{5}$ But some of these factors might discourage an agency from acting when action is appropriate; others might encourage an agency to act when action is inappropriate. This complicates the assumption by critics of judicial review, in which I previously acquiesced, that discouraging action is always a cost of review. It is possible that judicial review counterbalances factors that encourage agencies to act when action is not appropriate, in which case deterrence of action would be a further benefit of judicial review. ${ }^{6}$ In other words, that agencies are designed in some sense to be able to respond flexibly to changing circumstances does not mean that an agency should regulate whenever it perceives a problem that happens to fall within its regulatory authority. Instead, administrative law including doctrines of judicial review should be structured to encourage agency action when it is justified and discourage it otherwise.

In short, this article recognizes that judicial review is but one of a myriad of factors that affect whether an agency acts in response to a perceived problem. The article, however, is not simply a rebuttal of those who blame judicial review for inappropriate agency inaction. Rather, it is a first attempt to understand the more complex question of how those factors influence

${ }^{5}$ Note that taking no action in response to one problem would allow an agency to spend more resources on other problems. Hence, from the perspective of an agency, the issue of whether to change policy in response to a problem is really a question of optimizing regulatory priorities given the agency's budget constraints.

6 Viewed from an economic perspective, if an agency systematically overestimates the demand for regulation, then increasing the cost of regulation may cause the agency to choose a level of regulation that is closer to the optimal level than the level it would choose if judicial review did not impose such significant costs. The costs of judicial review act as a tax that has the effect of forcing the agency to internalize some of the external costs of regulating to the agency. $C f$. MARK SEIDENFELD, MiCROECONOMIC PREDICATES TO LAW AND ECONOMICS 64 (1996) (noting the potential of taxes to alleviate the affects of externalities as well as some of the problems with implementing this approach). Whether the actual level of regulation is closer to optimal with costly judicial review than without it would depend on the extent of the agency bias in evaluating demand, the extent of the costs of judicial review and the elasticity of supply and demand. In addition, if judicial review is structured so that it discourages inappropriate action more than appropriate action (i.e., imposes greater costs on inappropriate action than on appropriate action), then overall impact on social wealth is more likely to be positive because it would most greatly discourage inappropriate action. 
agencies' setting of their policy agendas. ${ }^{7}$ The Article does not contend that judicial review will encourage agencies to act only when, or even predominantly when, action is more appropriate. Instead it contends that one cannot easily generalize about the normative implications of judicial review on agencies' propensity to act, and suggests that one should not analyze the impact of judicial review on this propensity to act without looking both at the precise context in which the agency decision to act arises and the other factors that will influence that decision.

Given this contention, the Article is intended as a modest foray into a vast and complex subject and for that reason limits its scope to deliberate decisions made by agency heads about whether to change agency policy. As such, it excludes from its purview changes in policy that are incidental to lower level staff members simply trying to perform their day-to-day jobs and about which the agency generally may be unaware or not particularly concerned. Thus, for example, a policy adopted by an administrative law judge to resolve an issue of first impression in an adjudicated controversy within the agency's authority, where that policy does not reflect analysis by agency staff and serious consideration by the agency head, is not within the ambit of this Article. On the other end of the spectrum, policy choices dictated to the agency by other branches of government are also outside the bounds of this Article. Thus, the Article does not address agency action pursuant to a public demand by the President that an agency head commence a rulemaking proceeding to address a particular matter, a statutory prescription that leaves an agency no discretion to refuse to adopt a rule on a specified subject, or a court order that an agency engage in rulemaking on an issue.

It warrants noting that this article takes an "internal" approach to the question of how agencies decide to act, investigating the factors that affect the individuals within agencies responsible for such decisions, but not focusing on broad institutional arrangements that affect such decisions. In one sense, this is unexceptional because institutional influences operate by affecting individuals within the agency: the agency cannot act except via the conduct of those within it. Hence, an internal approach does not deny the relevance of external influences but incorporates those into the internal investigation of action, and, in fact, the Article explicitly considers how

${ }^{7}$ Few articles seek either to understand what motivates agencies in setting their agendas or to evaluate critically the impact of judicial review on agency propensities to regulate. One recent exception provides data suggesting that judicial review has not discouraged agency rulemaking to the extent that "ossification" critics contend. See Jason Webb Yackee \& Susan Webb Yackee, Is Federal Agency Rulemaking "Ossified"?: The Effects of Procedural Constraints on Agency Policymaking, 24 (Apr. 9, 2007) (unpublished manuscript, on file with author) (concluding that agencies appear readily able to issue a sizable number of rules, and do so, on average, relatively quickly). 
political and judicial review might modify the factors that influence agency personnel decision making. ${ }^{8}$ The internal perspective becomes controversial, however, to the extent that one believes that agency decisions about their policy agendas are dictated by external, institutional arrangements.

Some scholars have shown that, in a variety of contexts, Congress controls important decisions about agency agendas. ${ }^{9}$ Others have contended that the President exerts great influence over agency agendas. ${ }^{10}$ If either Congress or the President dictates the setting of agency agendas then the precise mechanisms that translate those arrangements into agency action become irrelevant, and arguably misleading. The folklore from the White House and the halls of Congress, however, is that the administrative state is a more unruly beast than these scholars would lead one to believe. " Moreover

${ }^{8}$ See infra notes $166-85$ and accompanying text.

${ }^{9}$ See, e.g., Mathew D. McCubbins et al., Administrative Procedures as Instruments of Political Control, 3 J.L. ECON. \& ORG. 243, 273-74 (1987) [hereinafter McCubbins et al., Administrative Procedures]; Mathew D. McCubbins et al., Structure and Process, Politics and Policy: Administrative Arrangements and the Political Control of Agencies, 75 VA. L. REV. 431, 435-44 (1989) [hereinafter McCubbins et al., Structure and Process]; Charles Tiefer, Congressional Oversight of the Clinton Administration and Congressional Procedure, 50 ADMIN. L. REV. 199, 200 (1998).

10 See, e.g., Elena Kagan, Presidential Administration, 114 HARV. L. REV. 2245, 2284-2302 (2001) (describing how the White House exerts great control over agency agendas).

${ }^{11}$ Presidential frustration with inability to control the bureaucracy has been noted repeatedly. Franklin Roosevelt is alleged to have remarked on the insufficient response of the career bureaucracy by saying:

The Treasury is so large and far-flung and ingrained in its practices that I find it is almost impossible to get the action and results I want .... But the Treasury is not to be compared with the State Department. You should go through the experience of trying to get any changes in the thinking, policy, and action of the career diplomats and then you'd know what a real problem was.

Richard E. Neustadt, Presidential Power and the Modern Presidents 37 (1990); see also James P. Pfiffner, Political Appointees and Career Executives: The DemocracyBureaucracy Nexus in the Third Century, 47 PUB. ADMIN. REV. 57, 57-58 (1987) (reviewing remarks of past Presidents regarding their distrust of agencies). President Nixon's White House Chief of Staff, Bob Haldeman, has said, "by 1971 Nixon had realized he was virtually powerless to deal with the bureaucracy in every department of the government." H. R. HALDEMAN WITH JOSEPH DiMONA, THE ENDS OF POWER 149 (1978). Congress's influence over the bureaucracy is even less direct, being limited to the power of the purse, of passing substantive legislation, and of embarrassing public officials by oversight hearings. See 147 CONG. REC. 3028, 3028-31 (2001) (statements of Rep. Linder, Rep. Northup, and Rep. Norwood chiding the Department of Labor for its decision to implement the ergonomics rule, and OSHA for finalizing it); McCubbins et al., Structure and Process, supra note 9, at 439, n.24 ("By exercising the power to fire heads of agencies and to issue executive orders, the President can influence policy 
there is an abundance of evidence to support the proposition that political principals cannot easily direct agency officials to follow their bidding. Whether staff members actually implement agency programs depends greatly on the members' own predisposition to work toward those programs. ${ }^{12}$ This is not to deny that Congress and the President greatly influence agency agendas, both by establishing procedures that stack the deck toward agency outcomes that favor constituents whom they want to benefit and by monitoring and funding programs that they desire. ${ }^{13}$ But, political principals use agencies to deliver rewards to constituencies precisely because an agency can flexibly react to changes in circumstances and preferences, and that flexibility allows it to deliver benefits to these constituencies more effectively and assuredly than Congress can deliver directly. Once the delegation of authority to the agency is made, however, the agency also has discretion to act in areas where the outcome is not dictated by political constraints. ${ }^{14}$ Even some who assert that the political branches effectively control agencies' agendas admit that Congress does not dictate whether an agency will act with respect to every policy issue on which the agency might act. Congress may simply not care about some of these issues, ${ }^{15}$ or it may have to allow the agency discretion with respect to some matters as a price for empowering the agency to act on those that Congress cares most about. ${ }^{16}$

without obtaining the agreement of the House and Senate. This opportunity for effective ex post response to noncomplying behavior implies that Congress is likely to be more concerned about structure and process than is the President.").

12 See John BREHM \& SCOTT Gates, Working SHIRKING AND SABotage: Bureaucratic Response to a Democratic PUBlic 79, 101-08 (2000).

13 See Mathew D. McCubbins, The Legislative Design of Regulatory Structure, 29 AM. J. POL. SCI. 721, 725-28 (1985) (describing structural arrangements that constrain the substantive discretion of an administrative agency); Barry R. Weingast \& Mark J. Moran, Bureaucratic Discretion or Congressional Control? Regulatory Policymaking by the Federal Trade Commission, 91 J. POL. ECON. 765, 780-91 (1983) (explanation of cutting of FTC budget in late 1970s using the legislative choice model).

14 See DaVID EPSTEIN \& Sharyn O'Halloran, DElegatTNG POWERs: A Transaction Cost Politics APPRoach to Policy MaKing UNDER SEPARATE POWERS 10, 27-29 (1999).

15 See Morris P. Fiorina, Congressional Control of the Bureaucracy: A Mismatch of Incentives and Capabilities, in CONGRESS RECONSIDERED 332, 343 (Lawrence C. Dodd \& Bruce I. Oppenheimer eds., 2d ed. Congressional Quarterly Press 1981) (discussing congressional reticence to interfere with agencies by establishing detailed regulations in areas of political conflict).

16 See, e.g., Antoine Faure-Grimaud \& David Martimort, Regulatory Inertia, 34 RAND J. ECON. 413, 422-25 (2003) (modeling how independence from political control increases ability of regulators to pursue policies different from those preferred by current majorities but also locks in the current majorities preferences by making it more difficult for future majorities to move policies towards their preferred points). 
Furthermore, in some instances an agency will pursue a policy that is not initially mandated by politics, but ultimately garners support from a political actor who can veto any attempt to force the agency to abandon the policy. ${ }^{17}$

It also warrants noting that those who claim that looking at the internal mechanisms is unnecessary can give no solace to critics of the impact of judicial review on agency agendas. Their posited perfect political control implies that the agency will do the bidding of its political principals regardless of the mechanisms by which that bidding is transmitted to the agency; if judicial review influences agency agendas it is because political principals want it to. ${ }^{18}$ In other words, accepting universal political determination of agency action would render futile any talk about changing judicial review to prevent it from being too burdensome and thereby unduly discouraging agency action. Political agenda determination implies that such discouragement reflects the desire of the political principals and if the judiciary were to ease the standard of review to encourage action, the political branches would respond by imposing procedural requirements or demanding that the courts reimpose burdensome review to induce the agency to return to the desired level of activity. In essence, critics who blame the courts for discouraging agency action implicitly adopt an internal approach. My analysis responds to these critics by working within their assumption that there is a set of policy questions that the agency truly has discretion whether to address, and that this set is sufficiently large and important to make this Article's inquiry interesting to those who want to understand how regulatory schemes operate.

17 See Mashaw, supra note 2, at 245-47 (describing model of political oversight demonstrating agency discretion); McCubbins et al., Structure and Process, supra note 9 , at 435-37, 439 (describing a formal model of political oversight demonstrating how the threat of overriding legislation still allows an agency discretion to choose from a set of outcomes different from the status quo, but arguing that enacting coalitions can stack the deck in favor of interest groups they seek to benefit). An example of such an issue was the FDA's decision to regulate tobacco products as drug delivery devices. Although the idea came from the agency, the Clinton White House not only supported such regulation, see David Kessler, A QUeSTION OF INTENT: A GREAT AMERICAN BATtle With A DEADLY INDUSTRY 331-33 (2001), describing White House reaction to the initial agency idea of regulating tobacco, it announced the proposed rule as if the idea came from the President. See Kagan, supra note 10, at 2282-83 (quoting President Clinton's White House Rose Garden announcement of the FDA tobacco proposed rulemaking).

${ }^{18}$ See Robert Glicksman \& Christopher H. Schroeder, EPA and the Courts: Twenty Years of Law and Politics, 54 LAW \& CONTEMP. PROBS. 249, 251 (1991). If political branches control agency action perfectly, were the courts to change the level of scrutiny of agency action in a manner that affected agency propensities to act on specific issues, then the political branches would simply alter agency procedures or the standard of judicial review in a manner that would reinstate the prior equilibrium between action and inaction. 
To get a handle on the question of how administrative law should respond to concerns about agency discretion to set regulatory priorities, the Article begins by reviewing the processes by which any organization, including an agency, goes about setting priorities. As part of this review, it describes the role of agency staff and agency heads in these processes. The Article proceeds to describe incentives for agency heads and staff that create agency costs-disparities between the goals of those who make the decisions and those whom the agency was meant to serve-and describes how these incentives might cause an agency to set a regulatory agenda that is not appropriate. Next, it identifies several psychological influences on decision makers that have the potential to cause the agency to adopt non-optimal regulatory priorities. The Article then turns to discuss agency structures and procedures, including the prospect of hard look review, that affect the influence of individuals within an agency on the setting of agency policy priorities. Such structures and procedures thus mediate the influences on individual decision making, potentially affecting the likelihood of an agency setting inappropriate policy priorities. Finally, the Article reviews two classic studies that blame judicial review for inappropriate agency failure to regulate: Richard Pierce's critique of the Federal Energy Regulatory Commission's (FERC) refusal to universally order utilities to provide access to their electricity transmission facilities in the 1980s, and Jerry Mashaw and David Harfst's analysis of the National Highway Traffic Safety Administration's (NHTSA) switch from issuing automobile safety standards to a system of recalls for defective automobiles in the 1970s. With respect to the first study, this Article concludes that judicial review did discourage FERC from regulating, but did so in a way that merely prevented FERC from proceeding without solving some fundamental problems posed by deregulation. With respect to the second study, this Article concludes that judicial review was not the primary factor causing NHTSA to abandon its auto safety standards program and that, to the extent it did delay NHTSA's issuance of such standards, such delay may have been warranted to keep the agency from getting too far ahead of the American public on the desirability of imposing costly auto safety standards.

\section{SETTING THE AGENCY REgULATORY AGENDA}

Like any organization, agencies act through the conduct of individuals. In analyzing the factors that influence agency decisions whether to respond to a regulatory problem, it is necessary to understand the input of various individuals in the process. Generally, the participants in the process can be broken down into two groups: agency heads and agency staff members. An agency head need not be an individual, but rather is the person or group statutorily authorized to make legally binding decisions for the agency. 
Usually an agency head also has authority to assign particular tasks to staff members, although in some agencies headed by multimember boards, the chairman is given the responsibility for overseeing day-to-day decisions about staff assignments. ${ }^{19}$ Even when the chairman has such responsibility, however, he cannot exercise it to defeat the will of the board. For instance, a chairman who disagrees with a majority of such a board about whether an agency should commence a regulatory project cannot simply refuse to assign staff to that project.

The roles of agency staff and the agency head depend to some extent on the process the agency uses to determine its policy agenda. Law does not dictate any procedures that govern an agency's determination of which regulatory problems to address. Thus, the processes for making such a determination run the gamut of mechanisms that organizations use to set priorities for action. Sometimes an agency will make the determination in a purposive manner, identifying the goals or missions of agency programs and evaluating means for achieving those goals. Other times the agency will act incrementally, adjusting existing policies only as needed to address issues that the agency is forced to confront. In still other situations, the problems agencies decide to address are a matter of the coincidence of a variety of factors conducive to agency action.

\section{A. Purposive Processes for Setting the Agenda}

Rationality is the traditional model of decision making. ${ }^{20}$ Rationality, as economists use the term, entails making the optimal decision-the decision that maximizes the net social value provided by the agency. ${ }^{21}$ Such rationality, however, is virtually impossible to achieve because it requires

${ }^{19}$ Marshall J. Breger \& Gary J. Edles, Established by Practice: The Theory and Operation of Independent Federal Agencies, 52 ADMIN. L. REV. 1111, 1165 (2000) ("Although the respective powers of a chairman and the agency as an institution differ from agency to agency, most chairmen are essentially the agencies' chief executive and administrative officers. They appoint and supervise the staff, distribute business among the agency's personnel and administrative units, and control the preparation of the agency's budget and the expenditure of funds."). See, e.g., 42 U.S.C. $\S 2000 \mathrm{e}-4$ (a) (2000) (describing the chairman of the Equal Employment Opportunity Commission as responsible for administrative operations); 18 C.F.R. $\$ 376.105$ (2007) (outlining the administrative responsibilities of the chairman of the Federal Energy Regulatory Commission).

${ }^{20}$ See Cass R. Sunstein, Introduction to BEHAVIORAL LAW AND ECONOMICS 1, 1 (Cass R. Sunstein ed., 2000) (noting that rational choice models "have dominated the social sciences, including the economic analysis of law").

${ }^{21}$ See, e.g., ROBERT COOTER \& THOMAS UlEN, LAW AND ECONOMICS 10-12 (3d ed. 2000 ) (recognizing maximization as a primary goal in the economist's view of decision making). 
consideration of every possible policy choice, an evaluation of the costs and the benefits of each choice, and a comparison of all to choose those that maximize the value minus the cost. ${ }^{22}$ In the real world of regulation, it is impossible to identify, much less completely understand, every possible policy choice open to an agency. ${ }^{23}$ In addition, the complexity of the implementation and impact of each choice and the subjective nature of the values served by agency policies render valuation of the costs and benefits of any one choice highly uncertain and contestable.

Nonetheless, agencies often do engage in a more practical version of trying to achieve the purposes served by the programs they administer when setting their agendas. This practical process still relies on evaluation of means of achieving identified ends, but rather than seeking to optimize such achievement, agencies often pursue a strategy of satisficing. ${ }^{24}$ Under such a strategy, an agency will identify the mission of the agency-the major goals it is meant to serve. Having identified such goals, the agency next examines problems that stand in the way of the achievement of those goals. Finally, the agency generates and considers potential solutions to such problems. The

22 See Herbert A. Simon, A Behavioral Model of Rational Choice, 69 Q.J. ECON. 99, 99-101 (1955). Even if information costs prevent decision makers from selecting the solution that would be best in the absence of such costs, decision makers might be able to use statistical techniques to choose rules of thumb that optimize outcomes based on any given set of decision criteria. See William J. Baumol \& Richard E. Quandt, Rules of Thumb and Optimally Imperfect Decisions, 54 AM. ECON. REV. 23, 24-26 (1964). Such choices, however, depend on criteria for decisions being objective and measurable, id. at 24 , and many regulatory decisions involve value laden criteria. In addition, regulatory policy decisions may be sufficiently unique to prevent the use of statistical curve fitting methods to evaluate rules of thumb to determine which are best. In any case, regulators sometimes are not aware and have not evaluated the rules of thumb they use to optimize them for the decisions they face, and psychologists have demonstrated that individuals often use biased (i.e., non-optimal) rules of thumb. See infra notes 113-14 and accompanying text. But see Gerd Gigerenzer, Peter M. TODd \& ABC ResearCH Group, SIMPLE HeURISTICS THAT MAKE US SMART 15 (1999) (identifying bounded rationality as the method through which people primarily make inferences and decisions).

23 Simon, supra note 22 , at 101.

243 HeRBERT A. Simon, MODELS OF BOUNDED RATIONALITY: EMPIRICALLY GROUNDED ECONOMIC REASON 295 (1997) [hereinafter SIMON, MODELS OF BOUNDED RATIONALITY] ("A decision maker who chooses the best available alternative according to some criterion is said to optimize; one who chooses an alternative that meets or exceeds specified criteria, but that is not guaranteed to be either unique or in any sense the best, is said to satisfice."); see also Herbert A. Simon, Rational Choice and the Structure of the Environment, 63 PSYCHOL. REV. 129, 136 (1956), reprinted in HERBERT A. SIMON, MODELS OF MAN: SOCIAL AND RATIONAL 261, 270-71 (1957) (introducing the notion of "satisficing" as an alternative to maximization); Herbert A. Simon, Theories of Decision-Making in Economics and Behavioral Science, 49 AM. ECON. REV. 253, 262-64 (1959) (discussing satisficing versus maximizing). 
agency includes within its agenda the adoption and implementation of solutions that it has considered that promise sufficient achievement of agency goals at reasonable cost, until it has no more money to spend on making or implementing policy. 25

The agency head attempting to satisfice will have to determine the goals of the agency and the value attributable to each identified goal. There are several choices an agency head can use in this process. He may look to the statute that creates the agency to divine a purpose or set of goals. He may look to the current Congress for insight, trying to determine what will please members of Congress who can affect the agency's budget or who might directly target the agency for legislative action if the agency displeases them. The current Congress may have a different set of priorities for the agency than the enacting Congress, or committee members who oversee the action of the particular agency may have a different mindset than those in that role when the agency's authorizing statute was passed. An agency head may look to the White House for guidance on the goals that the agency should pursue. This is especially likely to occur when the agency is executive and not independent, such as when the agency head is a member of the President's cabinet. Finally, the agency head can use her own ideological preferences to identify goals that she thinks the agency should pursue.

The agency head will next have to consider problems that interfere with the agency achieving its goals. Pragmatically speaking, an agency head will not be aware of all problems facing the agency. Generally, agency heads do not generate a list of problems, but rather are informed of perceived problems by various other participants in the process. Stakeholders in a regulatory scheme may meet with an agency head or her representative to complain about what they consider to be a problem. Congress and the White House again may play a prominent role in bringing problems to the attention of the agency head. Agency staff members may identify problems that come to light from their continued interaction with stakeholders and attempts to implement existing agency policy. Under the satisficing process, an agency will not attempt to identify all problems, but rather will attempt to identify those that seem to be significant, stopping the identification when enough significant problems have been identified for the agency head to feel comfortable that she will have meaningful policy choices to pursue. ${ }^{26}$

The agency head also must consider solutions to the set of problems that the agency might address. Again, an agency head cannot consider all possible solutions. Various stakeholders, as well as agency staff, may bring solutions

25 SimON, MODELS OF BOUNDED RATIONALITY, supra note 24, at 296.

26 See Simon, MODEls OF BOUNDED RATIONALITY, supra note 24, at 295 (noting that "a course of action satisfying a number of constraints, even a sizeable number, is far easier to discover than a course of action maximizing some function"). 
to the attention of an agency head. The agency head then must evaluate the solutions to determine which are likely to provide the most value in terms of agency achievement of its mission. Ultimately, an agency head will select problems that are both significant and for which solutions are available that will substantially alleviate the problems and hence further the agency achievement of its mission.

Agency staff plays an important role with respect to both identification and analysis of problems and solutions. With respect to identification, however, agency staff is merely one of many potential sources of information. Agency staff plays a more unique and therefore crucial function with respect to analysis of alleged problems, to determine whether they are sufficiently significant to warrant agency attention, and potential solutions, the impact of which must be discerned for the agency head to evaluate the extent to which the solution will help the agency achieve its objectives. Stakeholders outside the agency, by definition, have a direct interest in the agency policy choices, and an agency head may distrust the analyses they provide. Agency staff members generally are prohibited from participating in matters in which they have a direct financial interest in a policy outcome, ${ }^{27}$ and agency staff, as an institution, is traditionally portrayed as a neutral arbiter of policy debates. The role of staff, therefore, is to provide the agency head with complete and unbiased analyses.

Of course, that does not prevent agency staff from having its own agenda. A particular member of an agency's staff may have her own idea about what problems the agency should address and how it should address them. Members of a particular office within an agency might all prefer a policy outcome because they share a professional perspective that colors their ideas of what is a problem and what is a promising solution. Perhaps more significantly, staff members may share an interest in making their jobs as secure or easy as possible, which may lead to shirking and incomplete agency analyses of problems and solutions. Most importantly for the purposes of this Article, agency staff may face personal incentives to encourage or discourage an agency from acting when such a course would not be in the agency's best interest. To some extent agency structures and procedures may ameliorate improper staff encouragement or discouragement of agency action, but there remains a potential for agency staff to filter the information it provides the agency head in a manner that will improperly affect the agency head's propensity to take action.

27 See, e.g., 5 C.F.R. $\$ 2635.402$ (a) (2008) ("An employee is prohibited by criminal statute, 18 U.S.C. 208(a), from participating personally and substantially in an official capacity in any particular matter in which, to his knowledge, he or any person whose interests are imputed to him under this statute has a financial interest, if the particular matter will have a direct and predictable effect on that interest."). 
The Food and Drug Administration's regulation of cigarettes as drug delivery devices is an example of an issue that the agency decided to address after a purposive analysis. ${ }^{28}$ Tobacco use was a well known threat to public health, and the FDA made a deliberate decision to investigate whether it could fit tobacco products within its authority to regulate drugs and drug delivery devices. Following an extensive factual investigation by agency staff, 29 the head of the FDA, David Kessler, determined that regulation of cigarettes was a good use of agency resources because of the potential impact of such regulation on public health. ${ }^{30}$

\section{B. Incremental Processes for Setting the Agenda}

For many programs, agencies do not set an agenda based on a consideration of ends and means. In some cases, deciding how to prioritize various goals of the program may involve a complex interaction of a myriad of factors. ${ }^{31}$ In such cases, analyzing means and ends even using such practical approaches as satisficing requires a devotion of organizational resources that may not be justified in terms of the impact of the ultimate policy decision. The best an agency can then do is to tinker with its current programs to try to make them better serve their overall missions. Even when an agency conceivably could proceed purposively, it may not do so simply because purposive decision making requires a conscious effort and a devotion of resources to setting the agenda. Agency heads with scarce resources are likely to shy away from up-front devotion of resources to purposive analysis without knowledge that the policy outcome will justify that use of resources.

Of course, without doing a means-end analysis, the agency head may not know the potential impact of the potential policy outcomes. In other words, the agency head might find himself in a catch-22-he will not realize that a policy change warrants extensive analysis without first doing an analysis, and he will not order an analysis without knowing that the change justifies it. Hence, frequently agencies avoid explicit analysis of what policies to change, and instead set their agendas by "muddling through"-starting with their

28 The story of how the FDA came to take on the cigarette manufacturing industry was set out in DAVID KESSLER, A QUESTION OF INTENT: A GREAT AMERICAN BATTLE WITH A DEADLY INDUSTRY (2001).

29 An extensive overview of the investigation can be found in KESSLER, supra note 28 , at $95-260$.

${ }^{30}$ KESSLER, supra note 28 , at 62-63, 259-60.

31 Charles E. LindBlom, The INTELligenCE OF Democracy 138-39 (1965) [hereinafter LINDBLOM, THE INTELLIGENCE OF DEMOCRACY]. 
current programs and considering how those programs might be improved incrementally. 32

The role of agency staff increases in importance, relative to the agency head, when the agency proceeds incrementally. Often problems are identified when members of the staff, in the course of performing their day-to-day tasks, are faced with circumstances for which existing policy is inadequate. In such a situation, a staff member may simply propose a modification or extension of existing policy to cover the situation. ${ }^{33}$ Those outside the agency, or even outside the office in which the staff member works, may be unaware of the problem let alone to have analyzed it and come to a position regarding its resolution. Therefore, an agency head may be presented with a problem identified and described by a particular office in the agency, a greatly abbreviated set of decision options that reflect minor changes to existing policies, and an analysis by the office that identified the problem supporting its preferred policy option. Moreover, because the issue is raised in a way that does not signal widespread concern to the agency head, he is unlikely to conclude that a more deliberative process for resolving the problem, which would entail increased costs and delay, is warranted. Hence, the agency head's consideration of both whether to act and how to act is significantly constrained by staff analyses.

Agencies, like most large organizations, commonly muddle through as a means of implementing their goals. By its nature, however, incremental decision making downplays the significance of the decision being made, and thus frequently results in lower level agency staff making ultimate decisions that are never presented to the head of the agency as an action to which she should pay particular attention. An incremental change in policy often occurs simply by the action of a staff member whose job requires that he make some decision and who therefore directly faces the problem created by inadequate policy. That staff member likely will confer with colleagues in his office and run his solution by his supervisor, but in many cases agency heads are simply too busy to get involved in routine decisions made by staff, even when those decisions have policy consequences.

32 For a description of "muddling through," see LINDBLOM, THE INTELLIGENCE OF DEMOCRACY, supra note 31, at 143-51; Charles E. Lindblom, The Science of "Muddling Through," 19 PUB. ADMIN. REV. 79, 87-88 (1959) [hereinafter Lindblom, Muddling Through]. For a formal model of this method of decision making based on serial comparisons with change with the status quo, see Jonathan Bendor, A Model of Muddling Through, 89 AM. POL. SCI. REV. 819, 832-33 (1995) (concluding that many of the purported benefits of muddling through do not materialize in many empirically plausible contexts).

33 See Lindblom, Muddling Through, supra note 32, at 84-85 (suggesting that incremental decision making is at the heart of administrative behavior). 
An example of an agency policy that resulted from incremental decision making was the FAA's policy regarding whether hunting guides in Alaska who provide airplane transportation to and from remote hunting sites as part of their hunting packages had to comply with regulations governing commercial pilots rather than those governing private pilots. ${ }^{34}$ In 1963 the matter was initially brought to the attention of the regional FAA office in Alaska, which had the responsibility to advise guides about the regulatory requirements they had to meet in order to offer such air transportation. ${ }^{35}$ For thirty years, that office consistently interpreted FAA regulations not to mandate that guides comply with regulations governing commercial pilots as long as they did not charge for the transportation separately from the hunting package. ${ }^{36}$ In 1990 , after a reorganization to restore more control of regional offices to the FAA's central office, the agency was made aware of the regional office's long-standing interpretation. ${ }^{37}$ In 1992, the agency prepared a study of the safety concerns of allowing hunting guides to provide air service without meeting the standards for commercial pilots. ${ }^{38}$ Recognizing that a change in the interpretation would have a significant impact on Alaskan hunting guides and therefore the region, the FAA declined to act on the matter until 1998 when it issued an interpretative rule reversing the interpretation that had been adopted by the regional office. ${ }^{39}$ The issue was not one that involved a policy change with a significant national impact. Rather, the agency simply seemed concerned with closing a loophole in its definition of commercial travel that had been created by the interpretation of the agency's regional office and that it felt threatened the safety of clients of hunting guides. ${ }^{40}$

\section{Coincidental Processes for Setting the Agenda}

An agency may set its agenda by even less rational processes than muddling through. If an agency is faced with significant uncertainty about the relationship of its policies to its desired goals, or goals that are not well

${ }^{34}$ Alaska Prof'l Hunters Ass'n, Inc. v. Fed. Aviation Admin., 177 F.3d 1030, 1033 (D.C. Cir. 1999).

35 Id. at 1031 .

36 Id. at 1033 . The regional office had interpreted the provision of such plane service as incidental and hence not air transport for hire based on its reading of a 1963 $\mathrm{CAB}$ adjudicatory decision. Id. at 1031 .

${ }^{37}$ Id. at 1032.

38 Id. at 1033.

${ }^{39} \mathrm{Id}$.

40 The agency stated that, "[t]his local misunderstanding was not based on any agency interpretation or policy, and it must be corrected." 63 Fed. Reg. 4 (1998). 
specified, it might find that the best way to use its authority is to react to events rather than planning for them. An agency in this situation might find itself using the "garbage can model" of agenda setting. ${ }^{41}$

The garbage can model posits that there are four streams of events that constantly occur that relate to an agency's mission. ${ }^{42}$ These streams are: (1) problems in need of resolution; (2) solutions that are developed independent of problems; (3) participants or constituents willing to push an item onto the agenda; and (4) opportunities such as external events that focus public attention on a problem. ${ }^{43}$ When there is a concurrence of all four streams, then the agency will act. In essence, the garbage can model sees policy alternatives as being developed independent of any problem, just waiting for the appropriate problem to arise. When the problem does arise, the agency will act only if there are participants wishing to solve that particular problem and some catalytic occurrence that pushes the problem to the forefront of agency consideration.

Under the garbage can model of decision making, the role of staff in influencing the agency agenda is greatly decreased because the agency does not rely on explicit identification of a problem. Staff members, along with stakeholders in a regulatory program, constantly generate solutions to problems that do not yet exist or, if they do exist, problems that lack a sufficient constituency pushing for their resolution. But it takes circumstances independent of any conduct by the agency staff to catapult the agency to act on any problem. The decision to act does not require a comparison of different problems that the agency might tackle, or even an analysis of the impact of the potential solutions, both of which staff provides under a purposive approach to setting the agenda. Hence, agency staff's input in the process occurs prior to consideration of the problem for inclusion in the agency agenda, and the agency does not rely on staff as an exclusive source of input into the process.

Under the garbage can model, the role of agency head may also be less important to the ultimate decision whether to include an issue on the agency agenda. Although the ultimate authority to decide whether to pursue an issue belongs to the agency head, the decision essentially makes itself because the

41 See Michael D. Cohen et al., A Garbage Can Model of Organizational Choice, 17 ADMIN. SCI. Q. 1, 2-3 (1972); see also JAMES G. MARCH WITH CHIP HEATH, A PRIMER ON DECISION MAKING: How DECISIONS HAPPEN 198-206 (1994); JAMES G. MARCH \& JOHAN P. Olsen, REDISCOVERING InSTITUTIONS: THE ORganizational Basis OF POlitics $11-$ $14,28-30$ (1989).

42 MARCH \& OLSEN, supra note 41 , at 12 ("In pure form, garbage can models assume that problems, solutions, decision makers, and choice opportunities are independent, exogenous streams flowing through a system.").

43 Cohen et al., supra note 41 , at 3. 
streams of events leave the agency head little choice but to act. Hence, the agency head exercises less discretion when moving an issue onto the agency agenda because of the coincidence of the various streams of events that cause the agency to act. In fact, precipitating events often motivate the President or Congress explicitly to demand agency action to resolve the problem, which takes the decision to act outside the purview of this Article. Nonetheless, even when the agency's political principals do not demand action, coincidental streams of events can precipitate an agency change in policy.

An example of a policy outcome resulting from a garbage can model is the FAA's policy of requiring commercial airplanes to have smoke detectors. In 1975, the National Transportation Safety Board recommended that the FAA institute such a requirement as one of a multitude of recommendations the Board made to increase airline safety. ${ }^{44}$ The Board ignored this recommendation until 1984, when a fire in the lavatory of an Air Canada plane caused the plane to crash over Kentucky, killing twenty-three people. ${ }^{45}$ The FAA then required new planes to be equipped with smoke detectors, but did not require existing planes to install them until the 1996 ValuJet crash in the Florida Everglades killed 110 people. ${ }^{46}$ That crash was caused by a fire, of which the crew was unaware, in the cargo hold. ${ }^{47}$ Fire detectors would have alerted the crew, potentially allowing them to land the plane before the fire consumed it. ${ }^{48}$ Following the ValuJet crash, the FAA mandated that all commercial planes have smoke detectors on board. 49

\section{DECISION MAKERS’ INCENTIVES THAT AFFECT AGENCY PROPENSITIES TO ACT}

As the previous section illustrates, both agency staff and agency heads can influence agency choices about which policy issues to address. In this

44 See Lea Ann Carlisle, Comment, The FAA v. the NTSB: Now that Congress has Addressed the Federal Aviation Administration's "Dual Mandate," Has the FAA Begun Living up to its Amended Purpose of Making Air Travel Safer, or Is the National Transportation Safety Board Still Doing its Job Alone?, 66 J. AIR L. \& COM. 741, 746 (2001); see also Angela L. Brackbill, And What if it Catches on Fire?: The FAA's Ineffectual Stance on Post-Crash Fire Prevention in Airline Accidents, 60 J. AIR L. \& COM. 369, 396-397 (1994) (noting that "[t]he NTSB is responsible for many of the proposals for more advanced fire safety precautions which the FAA considers," and offering examples).

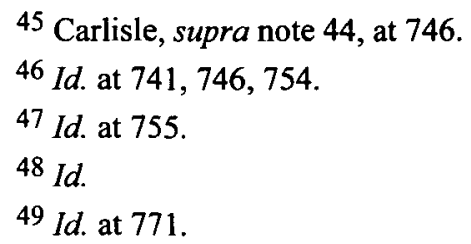


section, the Article lays out the incentives facing "economically rational" staff members and agency heads and analyzes whether these incentives are apt to encourage or discourage an agency's propensity to act.

\section{A. Staff Member Incentives}

Staff members face incentives based on job opportunities, both within the agency and within the interest groups that interact with the agency. They also have personal interests both in reaching their preferred policy outcomes and in avoiding work. Finally, staff members may be influenced by social pressures from those with whom they interact in performing their jobscolleagues within the agency, others from their profession with whom they have to deal on agency matters, and constituent groups whose interests they may represent within the agency.

\section{Employment Opportunities Within the Agency-The Prospect of Being Fired or Promoted}

Staff members' most immediate job incentives come from opportunities within the agency itself. At least in theory, they can be fired if they engage in conduct sufficiently outside the norms for their jobs; more importantly, their conduct can affect the probability that they will be promoted within the agency.

Staff members responsible for recommendations to agency heads may have little to lose and much to gain from proposing action, even when action might be of questionable value. On the one hand, staff members, protected by civil service rules, are unlikely to be fired or even demoted if policies they promote turn out badly or are not adopted by the agency. ${ }^{50}$ This does not mean that political appointees are powerless to sanction action by an agency staff member that angers the administration. Staff members' supervisors can transfer a staff member to an undesirable job, and even sometimes to an undesirable location. ${ }^{51}$ But, doing so for simply advocating action which the supervisor does not support when that action does not sabotage the administration's announced position on a policy issue can demoralize staff

50 See BREHM \& GATES, supra note 12, at 42 ("Evidence abounds demonstrating how coercive supervision (particularly in the form of punishment) is limited."); id. at 87 ("[S]upervisors agreed 'I do not have enough authority to remove people from their jobs if they perform poorly."'); $c f$. JAMES W. FESLER \& DONALD F. KeTTL, THE POLITICS OF THE ADMINISTRATIVE PROCESS 105, 123-24 (1991) (discussing how civil service systems make detection of shirking and separation more difficult).

51 JAMES P. PFIFFNER, The STRATEGIC PRESIDENCY: HITTING THE GROUND RUNNING 84 ( 2 d ed. 1996). 
members generally, and ultimately politically appointed supervisors within the agency will need to rely on those staff members' knowledge, support and loyalty to implement the administration's policies. ${ }^{52}$ Hence, supervisors are loath to punish employees for promoting agency action unless the staff member is seen as a saboteur of the administration's position on a policy issue. ${ }^{53}$

The recent move toward greater presidential control over agencies has resulted in some ability of politically appointed supervisors to discipline high-level staff members for poor performance. Thus, members of the Senior Executive Service, created in 1978 to "create a formal link between the career civil service and the political appointees who provide policy leadership and direction within federal agencies," 54 are subject to demotion and dismissal if they receive unsatisfactory performance ratings from their superiors. ${ }^{55}$ More generally, the Civil Service Reform Act of 1978, and more recently the management reform provisions of the Homeland Security Act have greatly increased the use of performance based personnel decisions at lower levels of agency staff. But, even these reforms do not clarify what constitutes good or bad performance. ${ }^{56}$ And the chance of being evaluated as unsatisfactory for aggressively pursuing policy change is extremely unlikely to earn an employee an unsatisfactory rating as long as the policy change is not inconsistent with the political values of her superiors because evaluation

52 See Hugh Heclo, A Government of Strangers 170-81 (1977); PfiffNer, supra note 51, at 81-82.

53 If a staff member's action does directly undermine the administration's policies, political supervisors may be willing to punish the "saboteur" as a means of signaling the consequences of sabotage to other employees, but usually, saboteurs are not supported by their professional colleagues, who by and large view their job as implementing the policies set forth by the political appointees in the agency. See MARISSA MARTINO Golden, What Motivates BureauCrats? POLITICS AND ADMINISTRATION DURING THE REAGAN YEARS 23-24 (2000); PFIFFNER, supra note 51, at 83; cf. HeCLO, supra note 52, at 228 (asserting that political appointees wisest response to sabotage by a staff member is "strengthening their outside contacts, extending their own lines of information and ... finding new points of countertension"). If the administration's policy is essentially to undermine the statutory mission of the agency, then the politically appointed supervisor contemplating a punitive reassignment will have to weigh the cost of alienating virtually the entire agency staff against the benefit of maintaining control over a potential runaway staff.

54 Patricia W. Ingraham, The Federal Public Service: The People and the Challenge, in THE EXECUTIVE BRANCH 283, 294 (Joel D. Aberbach \& Mark A. Peterson eds., 2005).

\footnotetext{
$55 \mathrm{Id}$.

56 Id. at 304-05.
} 
of the success or failure of such policies takes years, if it ever occurs, and by then the political superiors are long gone from the agency. ${ }^{57}$

On the other hand, in order to get promoted, a staff member may have to take action that distinguishes him from the multitude of others at his level within an office and makes his supervisor and others in the agency notice him. ${ }^{58}$ In other words, opportunities for promotions are limited and a staff member must affirmatively make a good name for himself in order to have any chance to secure a promotion. The protection from punishment along with the low probability of promotion within the agency, would lead a rational staff member to be a risk taker with respect to his personal investment in agency action. Staff members can take such risks by claiming a potential policy choice as theirs and promoting that policy aggressively.

Staff members often can make a positive impression by promoting action but are unlikely to make such an impression by opposing action. The standards for evaluating the efficacy of policy choices are uncertain (e.g., agency goals are not well defined and may be contextual) ${ }^{59}$ and evaluation of policy outcomes is too distant and too speculative for any quality based evaluative mechanism to work well. In essence, individuals who promote a policy are evaluated not on whether the policy turns out to be wise but rather on whether the policy is adopted by the agency. If it is, they are seen as having done well; if it is not, they usually are viewed just as they would have been had they never advocated the policy, although they may be viewed negatively for having wasted the agency's time with the proposed action.

In addition, it is more difficult for an individual to explain to his supervisors what he has been doing with his time if after studying a problem he asserts that no action is appropriate to solve the problem to which they assigned. ${ }^{60}$ For example, a police officer who arrests no one on his beat may do so because there is no crime or because he is lazy and chooses not to

57 See HECLO, supra note 52, at 103 (stating that "[t]he single most obvious characteristic of Washington's political appointees is their transience"); Ingraham, supra note 54, at 295 (noting the tension SES staff members face in order to gain the trust of political appointees who turnover on average every two years); see also BREHM \& GATES, supra note 12 , at 86 (reporting that agency staff do not believe that good workers stay with the agency and poor workers tend to be driven from the agency).

58 See EdWARd P. LAZEAR, PERSONNEl ECONOMICS 4, 25-37 (1994); see also BREHM \& GATES, supra note 12 , at 86 (Only "unusually high performance ratings may lead to pay raises or cash bonuses."); $c f$. David W. Moore \& B. Thomas Trout, Military Advancement: The Visibility Theory of Promotion, 72 AM. POL. SCl. REV. 452, 462-63, 467-68 (1978).

59 See JAMES Q. WILSON, BUREAUCRACY: WHAT GOVERNMENT AGENCIES Do AND WHY THEY Do IT 131 (1989) [hereinafter WILSON, BUREAUCRACY] (describing the difficulty in holding managers accountable for achieving a goal).

60 See id. at $155-56$. 
investigate the crimes sufficiently. ${ }^{61}$ Thus, an officer who arrests no one will have to spend time justifying what he does on the beat to convince his supervisor that he is working, while one who makes some arrests will not have to do so. ${ }^{62}$ As a result, there may be an incentive to arrest individuals who the officer believes did not commit a crime so long as the officer can justify the arrest. Translated into a context where a staff member can propose action or refrain from doing so, proposed action shows that the person has been thinking about the problem. In addition, proposed actions usually only have to be defended against the alternatives of maintaining the status quo and variations on the proposed action. Non-action must be justified in terms of all potential alternatives. Hence, accountability to superiors favors action.

\section{Employment Outside the Agency and Capture}

Staff members also face incentives from career opportunities outside the agency. They might alter their propensity toward promoting agency action if doing so would affect their opportunities for employment with private stakeholders with whom they deal. ${ }^{63}$ For example, a staff member who develops a reputation for working hard and for having knowledge of an issue is more likely to attract the attention of a potential outside employer. ${ }^{64}$ Agency action associated with a staff member may facilitate her building such a reputation. 65 Thus, the same factors that give rise to promotion opportunities within the agency will also increase the prospect of later outside employment.

One way in which the prospect of outside employment can create incentives different from those created by the potential for promotion within the agency is through "capture." 66 Capture describes mechanisms by which a regulated entity uses benefits that it can bestow on an agency staff member to induce that member to act on behalf of the entity. ${ }^{67}$ The mechanism by which capture has traditionally been hypothesized to occur is the promise of future employment or on the job benefits in return for favorable treatment of the

61 Id. at 155.

62 Cf. Eugene Bardach \& RoBert A. Kagan, GoING By the BoOK: THE Problem OF REGULATORY UNREASONABLENESS 158 (1983) (noting that monitoring enforcement by considering the number of citations an inspector issues will lead to counterproductive citation of every technical violation).

63 See Paul J. Quirk, Industry Influence in Federal Regulatory Agencies 143-74 (1981).

64 Id. at $149-50$.

65 Id. at 150.

${ }^{66}$ For a general discussion of agency capture, see generally id. at 173-74.

${ }^{67} I d$ at 4. 
entity. ${ }^{68}$ For several reasons, traditional capture is not as prevalent a phenomenon for staff members engaged in the policy-making process as once thought. ${ }^{69}$ Laws limit the extent to which entities can legally bestow benefits on staff members. In most jurisdictions, a staff member cannot interact with their former agencies on behalf of a client or employer for some period of time after he leaves the agency. There are also limits on material gratuities that private entities interested in the business of the agency can bestow on staff members.

Of course, the fact that promising future employment or other benefits in return for preferential regulatory treatment is illegal does not ensure that such agreements never occur. But there are reasons why the illegality of such agreements is likely to discourage them effectively. Enticing a staff member into such an agreement will require that the stakeholder create a credible reputation for rewarding those who have acted in its favor that can be verified by the staff member, but which will not be revealed to the watchdogs who look out for such illegal conduct. Moreover, even if the staff member were to enter into such an agreement, a stakeholder would bear a significant cost to monitor that the member was upholding his end of the agreement. This is especially true when the issue of concern is development of policy of general applicability, for then the agency process for reaching a decision is not limited to a public record. A regulated entity may not have access to all the memos and oral advice offered by the staff member to decision makers within the agency. In the context of development of a general policy, a stakeholder may also have less incentive to enter into a "capture" agreement. The influence of any one staff member on the outcome is usually not dispositive. Generally such a decision will involve numerous factors, and a staff member likely will provide input only with respect to one such factor. In addition, a staff member who is involved in formulating policy frequently will be supervised by someone else in his office, or will have to convince his colleagues in his office about his policy recommendations. A supervisor or colleague is likely to be able to identify and correct questionable analyses. ${ }^{70}$

${ }^{68} \mathrm{Id}$. at 19.

${ }^{69}$ It may be more of problem with respect to staff members responsible for enforcement and procurement, because, first, such individuals generally can make a decision that affects the interests of a regulated entity without having to run that decision by others in the agency, and second, it is easier for regulated entities to monitor such individual decisions. See, e.g., Alan Bjerga, U.S. Officials Blamed in Boeing Case, Monterey County Herald, June 8, 2005, at A3; Joseph L. Galloway, Defense Procurement: This Deal Stank 'Like Rotten Fish', MIAMI HERALD, June 19, 2005, at L5; Leslie Wayne, An Anxious Time for Boeing As a Fired Worker Starts to Talk, N.Y. TIMES, June 16, 2004, at Cl.

${ }^{70}$ Note that in the context of an adjudication applying law or policy, the input of the individual staff member becomes part of a record that is available to the regulated entity 
The recent trend toward greater executive control over agency policy has also made capture of staff less likely because staff members have less influence over the policy an agency pursues. ${ }^{71}$

Something akin to capture can also occur if the stakeholder has information that the staff member needs to do his job. The stakeholder can threaten to withhold the information unless the staff holder cooperates by supporting the policies preferred by the stakeholder. ${ }^{72}$ Although agencies generally have either the capability of developing information from other sources or the authority to demand such information from stakeholders, forcing a staff member to have to demand specific information and verify its authenticity and veracity can increase the demands of a staff member's job significantly over the workload the member would face if the stakeholder volunteered relevant information. Hence, the stakeholder can "bribe" the staff member by altering the ease with which he can obtain the information. This mechanism for capture relies on staff members' preference for decreasing their work load. It is not clear, however, that staff members actually share such a preference. Even if they do, that preference may be mediated by their desires to see themselves as performing their jobs well. ${ }^{73}$

making monitoring of the capture agreement easier. See Administrative Procedures Act, 5 U.S.C. $\$ \S 554-57$ (2006) (specifying formal procedures for adjudication and prohibiting ex parte communications to the decision maker in such adjudications). Note also that in the context of applying law or policy outside of an adjudication, such as in the investigatory stage, an individual staff member may have a greater influence on the outcome of a matter. For example, an inspector can essentially forgive a violation of regulatory requirements by simply not reporting it. See BARDACH \& KAGAN, supra note 62, at 40; Michael LiPSKY, STREeT-LeVel BureaucraCY: Dilemmas of THE INDIVIDUAL IN PUBLIC SERVICES 13 (1980). Thus, the incentives for an entity to seek capture are greater in the application context.

71 Thus, the extent to which career staff members interact with political appointees who make the ultimate policy decisions and with representatives of interest groups who have a large stake in the policy debates has decreased with the rise of the "administrative presidency." See Joel D. Aberbach, The Executive Branch in Red and Blue, in A REPUBLIC DIVIDED 157, 184 (The Annenberg Democracy Project ed., 2007).

72 See Stephen Croley, White House Review of Agency Rulemaking: An Empirical Investigation, 70 U. CHI. L. REV. 821, 834 (2003); Clayton P. Gillette \& James E. Krier, Risks, Courts, and Agencies, 138 U. PA. L. REV. 1027, 1067 (1990) (asserting that "some groups enjoy a comparative advantage in catering to administrative needs and desires [for information] ... there arises the danger that agency attention will be captivated by too narrow a range of interests and be diverted from an appropriately public perspective").

${ }^{73}$ Agency staff members' desire to shirk is addressed infra note 76 and accompanying text. Need for information can also affect institutional structures that in turn may influence agency staff members to identify with regulated entities. An agency staff member assigned to work on site at the plant of a regulated entity in order to gather necessary information is apt to socialize with employees of the entity with whom he works and therefore may be predisposed to see an issue from that entity's perspective. 
This discussion is not meant to suggest that regulated entities cannot unduly influence staff members, but rather only that such influence on staff involved in developing agency policy are not particularly prone to bias in return for the promise of material benefits from those entities. It also deserves notice that, even if agency staff is subject to capture, that phenomena is unlikely to influence decision makers systematically to favor or oppose agency action on an issue. Whether a regulated entity prefers an agency to act depends on the precise circumstances of the action at issue.

\section{Institutional Capture}

Another kind of capture that can occur is what I call institutional capture. Essentially, staff members have an incentive to maintain the agency performing its current tasks, or else they will find themselves with no job to perform. ${ }^{74}$ Staff self-interest in perpetuating the role of the agency can discourage agency action that opens the possibility of a fundamental shift in what the agency does. It would, however, encourage action within the existing regulatory paradigm as a means of continuing the justification for staff members' current positions. ${ }^{75}$

\section{Shirking and Leisure}

Theorists who have written about the motivation of agency staff members have recognized that, in addition to direct penalties and rewards, economically rational bureaucrats have an interest in maximizing their leisure, which translates into a preference for minimizing their workloads. If supervisors have little authority to penalize lazy workers, staff members have an incentive to do little work for their pay. ${ }^{76}$ Recent models and empirical

Hence, the need for information can create institutional structures that predispose agency staff to favor the views of those they regulate. This phenomenon will be addressed later in this Article in a discussion of issue networks. See infra Part III.A.5.

74 See Mark Seidenfeld, A Civic Republican Justification for the Bureaucratic State, 105 HARV. L. REV. 1511 , 1570 n.289 (1992).

75 At some level, the material incentives to maintain the agency in its current form mirror the social incentives staff members experience to upset stable relationships within issue networks to which they belong. See infra notes 93-95.

76 See GoLDEN, supra note 53, at 21; see also Armen Alchian \& Harold Demsetz, Production, Information Costs, and Economic Organization, 62 AM. ECON. REV. 777, 780 (1972) (concluding that cost of detecting relaxation means that some shirking will occur in any firm); id. at 782 (noting the monitor must also be given the authority to alter the employee contract when shirking is detected); $c f$. William A. Niskanen, A Reflection on Bureaucracy and Representative Government, in THE BUDGET-MAXIMIZING BUREAUCRAT: APPRAISALS AND EVIDENCE 13, 16-17, 19-20 (Andre Blais \& Stéphane 
studies question the extent to which agency staff members seek to minimize their workloads. Data suggest that in many contexts, agency staff members prefer policy accomplishments, recognition from others or agency loyalty, and consonance to their perceived role over pecuniary rewards or leisure.77 Nonetheless, material rewards are among those that bureaucrats identify as an important reason they work in agencies, and leisure is a form of a pecuniary reward for employees. ${ }^{78}$

Staff members can avoid work by not identifying potential action items within their responsibilities within the agency. If a staff member is not involved in a matter of high priority within the agency, he will be subject to less scrutiny than if he is. A staff member may be able to act less carefully on a matter that has not attracted attention of a supervisor or others higher up in the agency.

But, once a matter is identified as warranting at least serious consideration, it is not clear that inaction increases leisure time. That depends on the time a staff member will have to spend justifying not pursuing the matter further versus the time it would take to address the matter. As noted previously, it may be less work for a staff member to justify to his supervisor an action option rather than inaction. Even if the work to justify action is equal to the work to justify inaction, where the staff member is not ultimately responsible for deciding whether the agency will act, justifying inaction becomes riskier. An effort justifying no action is wasted if the agency pursues the matter further, for in that circumstance the staff member will have to redo her analysis to analyze the agency action, whereas analysis supporting action both satisfies one's supervisor that one has been doing something and leaves the member less work to do if the agency decides to pursue the matter.

Dion eds., 1991) (contending that because bureaus generally have monopoly power over the services they supply and their sponsors do not benefit directly from the services they supply, workers in bureaus derive greater non-monetary surplus, e.g. leisure, pursuit of ideological preferences, etc., than the workers in competitive organizations). See generally Bengt Holmström, Moral Hazard and Observability, 10 BELL J. ECON. 74 (1979) (demonstrating that in a principal-agent model, it would be prohibitively expensive to design an incentive scheme to eliminate shirking).

77 See BREHM \& GATES, supra note 12 , at 75, 77-83, 108; GOLDEN, supra note 53 , at 20-22, 26-29; John D. Dilulio, Jr., Principled Agents: The Cultural Bases of Behavior in a Federal Government Bureaucracy, 4 J. PUB. ADMIN. RES. \& THEORY 277, 315-16 (1994).

78 See BREHM \& GATES, supra note 12 , at $80-81$. 


\section{Solidary Benefits, Issue Networks, and the Status Quo}

Utility maximizing staff members have preferences in addition to material benefits such as pay or leisure. Humans are social animals, and they have a strong desire to belong to social groups. ${ }^{79}$ According to social identity theory, groups actually make up part of most individuals' self-identity. ${ }^{80}$ Individuals excluded from groups with which they identify experience anxiety and low self-esteem. ${ }^{81}$ Exclusion can even result in degradation of cognitive functioning. ${ }^{82}$ Not surprisingly then, individuals will adopt behavior that makes them feel that they fit into a group with which they identify. 83

Individuals may conform to the behavior of others in a group for several reasons. An individual may conform to avoid distinguishing himself from the group and thereby risking being singled out or rejected. An individual may also conform to group behavioral norms because he may use the behavior of those with whom he shares common characteristics as a cue to what behavior is appropriate for him. ${ }^{84}$ Individuals may even rely on the behavior of others

79 See Roy F. Baumeister \& Mark R. Leary, The Need to Belong: Desire for Interpersonal Attachments as a Fundamental Human Motivation, 117 PSYCHOL. BuLL. 497, 499 (1995) (describing the human need to belong as innate).

80 See Michael A. Hogg, Deborah J. Terry \& Katherine M. White, A Tale of Two Theories: A Critical Comparison of Identity Theory with Social Identity Theory, 58 SoC. PSYCHOL. Q. 255, 259-62 (1995).

${ }^{81}$ See Roy F. Baumeister \& Dianne M. Tice, Anxiety and Social Exclusion, 9 J. SOC. \& CLIN. PSYCHOL. 165, 167, 189 (1990) (describing that individuals experience distress when excluded from social groups).

82 See Roy F. Baumeister, Effects of Social Exclusion on Cognitive Processes: Anticipated Aloneness Reduces Intelligent Thought, 83 J. PERSONALITY \& SOC. PSYCHOL. 817, 825 (2002); see also Stefan Schultz-Hardt et al., Biased Information Search in Group Decision Making, 78 J. PERS. \& SOC. PSYCHOL. 655, 655 (2000) (finding that strength of individual preferences for information supporting their views increases the more others in a group initially share the same views).

${ }^{83}$ Michael A. Hogg \& John C. Turner, Social Identity and Conformity: A Theory of Referent Information Influence, in 2 CURRENT ISSUES IN EUROPEAN SOCIAL PSYCHOLOGY 139, 149 (Willem Doise \& Serge Moscovici eds., 1987); Michael A. Hogg, John C. Turner \& Barbara Davidson, Polarized Norms and Social Frames of Reference: A Test of the Self-Categorization Theory of Group Polarization, 11 BASIC \& APP. SOC. PsYCHOL. 77, 79-80 (1990).

${ }^{84}$ See Ricky W. Griffin et al., Objective and Social Factors as Determinants of Task Perceptions and Responses: An Integrated Perspective and Empirical Investigation, 30 ACAD. MGMT. J. 501, 501 (1987) (reviewing workplace conformity); Hogg et al., supra note 80, at 259-60; see also Gerald R. Salancik \& Jeffrey Pfeffer, A Social Information Processing Approach to Job Attitudes and Task Design, 23 ADMIN. SCI. Q. 
as a means of gauging the accuracy of their own perceptions of reality. ${ }^{85}$ In fact, political scientists who study interest groups have recognized that people join and stay in groups in large part because of solidary benefits-the feeling of well being they derive from being part of the group and participating in a group's activities. ${ }^{86}$

Agency staff members potentially can define their working selves by inclusion in several groups. First, staff members may be part of a group specifically formed to analyze a particular problem within an agency's bailiwick and may have allegiance either to the agency or to the working group of which they are part. ${ }^{87}$ Second, staff members almost always are part of some office at the agency. This office likely includes other staff members with similar professional training and backgrounds and hence shared professional norms. ${ }^{88}$ For example, Counsel's Office in an agency will have lawyers who, by virtue of their legal schooling, see themselves as fulfilling a role of implementing law. Members of the agency "Office of Policy Analysis," usually will be economists, who may share a norm of requiring fairly convincing justification before supporting government intervention into working markets. ${ }^{89}$ In other words, staff members may feel an allegiance to their office within the agency. ${ }^{90}$ Because the individuals in these offices often have similar professional backgrounds and perspectives, and are assigned similar roles in various agency matters, staff members are particularly apt to take behavioral cues from their compatriots within these offices. Finally, staff members may see themselves as serving an outside

224, 231 (1978) (describing norms and expectations as influencing rationalizations for behavior).

${ }^{85}$ See Solomon Asch, Effects of Group Pressure upon the Modification and Distortion of Judgment, in GROUPS, LEADERSHIP AND MEN 177, 190 (Harold S. Guetzkow ed., 1951).

${ }^{86}$ Robert H. Salisbury, An Exchange Theory of Interest Groups, 13 MIDWEST J. POL. SCI. 1, 16 (1969).

87 See GOLDEN, supra note 53, at 28-29 (discussing agency "esprit de corps" as a factor motivating staff behavior); Thomas O. McGarity, The Internal Structure of EPA Rulemaking, 54 LAW \& CONTEMP. ProBS. 57, 92 (1991); Mark Seidenfeld, Cognitive Loafing, Social Conformity, and Judicial Review of Agency Rulemaking, 87 CORNELL L. REV. 486, 543 (2002).

88 See Mark Seidenfeld, Bending the Rules: Flexible Regulation and Constraints on Agency Discretion, 51 ADMIN. L. REV. 429, 465 (1999); Seidenfeld, supra note 87, at 544-45.

${ }^{89}$ Cf. Mark Seidenfeld, The Psychology of Accountability and Political Review of Agency Rules, 51 DUKE L.J. 1059, 1068-75 (2001) (discussing likely influence of the make-up of the OIRA/OMB staff).

${ }^{90}$ See GOLDEN, supra note 53, at 164-65 (noting influence of professional perspectives of different offices within the agency); Seidenfeld, supra note 3, at 508 . 
constituency, often defined by either the values of their professions or by the role that their office plays in the agency decision-making process. ${ }^{91}$ Thus, in the Environmental Protection Agency, health scientists may interact with members of the medical profession and other scientists who see their job as ensuring that parties whom the EPA regulates do not behave in a manner that threatens the health of significant portions of the population. Engineers, however, might interact with technically trained individuals who work for regulated entities and hence might see their role as facilitating introduction of cutting edge technologies.

The strength of any particular staff member's allegiance to each of these various groups will affect her attitude toward agency policy and her propensity to promote or discourage agency action. In many instances, group allegiances will reinforce one another. For example, if a constituent group shares professional norms with all the staff members in a particular agency office, then a staff member in that office can act to reinforce his inclusion simultaneously both in the agency office and the outside constituency group. Nonetheless, because agency staff members can identify with various work related groups, the potential allegiances of agency staff can be complex, and often depend on the precise structure and history of the agency. Factors such as whether the agency is dominated by offices staffed by members primarily from a single profession, or whether the agency historically has an ethos of political independence rather than one of implementing the will of political appointees who are in charge at any moment will affect such allegiances. ${ }^{92}$ Fortunately, the policy issues on which this Article focuses usually occur at a lower level of visibility than macro policy, which becomes part of public political debate, and at a higher level than micro policy, which addresses such day-to-day matters as the enforcement or implementation of established policy or technical matters, each of which are of little concern to more than a handful of stakeholders. Thus, for the policy issues on which this Article focuses, analyzing the interaction of interest groups that compete for their preferred agency outcomes at the system level simplifies the complex influence of staff member allegiances. Such systems of interest groups

91 See PFIFFNER, supra note 51, at 83 (noting that career staff members take pride in their craft and satisfaction in accomplishing the mission of the agency); Mark Seidenfeld, Bending the Rules: Flexible Regulation and Constraints on Agency Discretion, 51 ADMIN. L. REV. 429, 454, 462, 467 (1999); Mark Seidenfeld, Empowering Stakeholders: Limits on Collaboration as the Basis for Flexible Regulation, 41 WM. \& MARY L. REV. $411,436,442-44$ (2000).

92 See GOLDEN, supra note 53, at 154-66 (discussing how different structures, norms and histories of agencies affect the likelihood of cooperation versus resistance to new political appointees). 
competing for benefits that an agency can bestow have come to be known as policy subsystems or issue networks. ${ }^{93}$

Subsystems are characterized by complex issues and a multiplicity of actors, most of whom participate based on knowledge of the issues involved. Thus, participants include stakeholder representatives, agency, congressional and sometimes White House staff, and academics. Some subsystems are competitive and in great flux..$^{94}$ Others, however, are dominated by particular participants/stakeholders, and are quite stable. ${ }^{95}$ Even competitive subsystems can be stable if they are in equilibrium, which may reflect the state of a majority of such systems in the political domain. For subsystems in flux, participants may move in and out of the network as the importance of the issue to potential stakeholders or the salience of the issue changes. For stable subsystems, however, the same set of participants may inhabit the issue network over a long period of time. Such participants may get to know one another, what to expect from others and what others expect from them to maintain the stability of the system. In essence, participants, including agency staff members, begin to identify with the group of individuals who participate in the issue network.

Individuals within a stable policy subsystem, therefore, will feel social pressure not to scuttle the equilibrium of that subsystem. Such individuals may begin to feel allegiance to the subsystem and the other players in it. If they disrupt the equilibrium then they impose costs and uncertainty on others who participate in the subsystem. Over time the structure of a stable subsystem feels normal and begins to seem inevitable. Hence, individuals will not think about proposing policy changes inconsistent with the existing structure/equilibrium. If a policy subsystem becomes destabilized, the propensity not to think about policies inconsistent with the existing system or of scuttling the existing equilibrium vanishes. Instead, the norm becomes advocacy for change that benefits the group with which the participant in the network identifies; hence it becomes more likely that a staff member will promote action to alter policy. Thus, the structures of issue subsystems will tend to discourage agency staff members who inhabit a stable subsystem from acting as crusaders to elevate the importance of that issue within the agency and to seek a change from the status quo. Once an agency indicates serious interest in a potential policy change for a particular subsystem,

${ }^{93}$ See Hugh Heclo, Issue Networks and the Executive Establishment, in THE NEW AMERICAN POLITICAL SYSTEM 87, 102 (A. King ed., 1978); James A. Thurber, Dynamics of Policy Subsystems in American Politics, in INTEREST Group Politics 319, 325-26 (Allan J. Cigler \& Burdett A. Loomis eds., 3d ed. 1991).

94 See Thurber, supra note 93 , at 330.

95 See id. at $327-30$. 
however, staff members have an incentive to support change and hence action.

\section{Personal Ideological Preferences}

Just as material and solidary benefits can motivate agency staff members, so too can their personal policy preferences. This is not to suggest that a staff member's ideology is the sole determinant of what actions he will take. In fact, there is much evidence that staff members in most agencies will act to support the policies of their politically appointed overseers, whether or not the members agree with these policies, because of an ethos or role conception that their job is to implement what the political appointees dictate. ${ }^{96}$ At the same time, in some agencies, especially those in which many staff members share a preference for policy outcomes different from those chosen by their political principals, staff members may engage in shirking or sabotage to undermine the achievement of such outcomes. ${ }^{97}$

Frequently, especially for young agencies that are perceived as having an important mission, staff members join the agency because they share this mission. ${ }^{98}$ When policy ideology motivates many staff members to choose to work for an agency, such members are likely to have personal preferences about the actions the agency might take. ${ }^{99}$ If policy choices facing an agency involve whether to establish a regulatory program, then propensity to prefer the agency mission will favor action. If, however, the policy choices involve whether to cut back on established regulatory programs (i.e., whether to deregulate), then propensity to share the agency mission will favor inaction.

96 See GolDEN, supra note 53, at 51, 58-59; PFIFFNER, supra note 51, at 77-81; Francis E. Rourke, BuREAUCRACY, POLITICS, AND PUBliC Policy 92 (1969).

97 See BREHM \& GATES, supra note 12, at 196 ("When the preferences of subordinates run counter to the public ... then the role of fellow subordinates can lead to ... disastrous breaches of civic authority ...."); see also PFIFFNER, supra note 51, at 85 ("Bureaucratic resistance to presidential interests and directives is inevitable ... . [But c]areer bureaucrats . . . are not the primary instigators . ...").

98 MaRVer H. BERnSteIn, THe JoB OF THE Federal EXeCUTIVE 163-64 (1958); ANTHONY DOWNS, INSIDE BUREAUCRACY 5-6 (1967); see also ROBERT MARANTO, POLITICS AND BUREAUCRACY IN THE MODERN PRESIDENCY 69-71 (1993) (presenting data confirming that careerists' ideology is significantly linked to organizational mission).

99 Joel D. Aberbach \& Bert A. Rockman, Clashing Beliefs Within the Executive Branch: The Nixon Administration Bureaucracy, 70 AM. PoL. SCI. REV. 456, 461-63, 466 (1976) (finding that civil servants in the social services agencies held more liberal ideologies than those in other agencies); see also SHIRLEY ANNE WARSHAW, POWERSharING: White House-Cabinet RELATIONS IN THE MODERN PRESIDENCY 130 31 (John Kenneth White ed., 1996) (Reagan used an ideological litmus test to limit internal policy initiatives contrary to the administration's agenda and ensure bureaucratic responsiveness.). 
When policy choices reflect different means of pursuing regulation, then there will be no systematic correlation between sharing mission and favoring agency action.

Staff members' ideological preferences are affected by their background and role within the agency. For example, engineers may tend to think technology can solve problems; environmentalists may think the opposite; economists may have a stronger belief that markets are the best solution to regulatory problems. Hence, whether a particular member's professional training would encourage him to prefer agency action on a matter will depend on the nature of the training and professional norms of the agency office in which the member works. It will also depend on the congruence of the proposed action to those norms. In short, the likelihood of any staff member being ideologically motivated to prefer inaction to action will depend on the details of the proposed action.

\section{B. Agency Head Incentives}

Agency head incentives, like those of agency staff members, can be broken down into career advancement, social incentives and ideological goals.

\section{Career Advancement}

The possibility for career advancement will depend on whether the agency head is a "careerist," a "politician," or a "professional."100 Unlike politicians and professionals, careerists do not have significant opportunities outside the agency for employment because their knowledge and experience do not easily transfer to other agencies or private institutions. They have risen through the ranks and have reached the apex of the opportunities open to them. Their incentive, therefore, is to maintain their positions as agency heads. Careerist agency heads can best maintain their positions by lying low and not doing anything that attracts attention. Hence, unless they are faced

${ }^{100} \mathrm{My}$ three category typology of agency heads is based on James Wilson's dichotomy between political and career agency heads, WILSON, BUREAUCRACY, supra note 59, at 197-200, and his description of three types of agency employees, James Q. Wilson, The Politics of Regulation, in THE POLITICS OF REGULATION 357, 374-82 (James Q. Wilson ed., 1980). With respect to agency heads, I have distinguished between careerists from within the agency and professionals from outside the agency because each has different aspirations and constituencies. Although I specify three categories of agency heads, and therefore am able to make finer distinctions than did Wilson, even these three categories represent typologies that are somewhat oversimplified. In reality the types are not distinct. Cf. WILSON, BUREAUCRACY, supra note 59, at 197 (noting that executives in agencies can be "complicated combinations of the two" types Wilson describes). 
with a problem that demands action, such as one that triggers the coincidental model of agency decision making, careerists have an incentive to avoid taking on new regulatory issues. ${ }^{101}$

Both political and professional agency heads have career prospects primarily outside the agency. This is in part because agency goals are so vague, controversial, or difficult to measure, and agency head tenure generally so short, that agency heads must look outside the achievement of the agency for rewards. ${ }^{102}$ In addition, politicians and professionals are not interested in remaining with the agency for their entire careers. Frequently, they have other aspirations.

For politicians, being an agency head may allow them to garner support from their political parties and other politicians that they can parlay into jobs as heads of more prestigious executive departments or as elected officials. Agency heads can generate political support and even subsequent endorsements in later elections by being loyal to the party and the current administration. Whether sidling up to the White House and leaders on Capitol Hill will create any predilection for action on any issue depends on the precise issue and circumstances surrounding that issue.

An agency head with political aspirations will also try to generate public name recognition by taking action that attracts the attention of the press. But not all press is good press. Hence a political agency head will tend to take action for which she can claim credit and avoid action for which she can be blamed. ${ }^{103}$ For example, regulation that decreases the likelihood of an airplane crash is unlikely to garner credit for the head of the FAA because the public expects airplanes to be safe. ${ }^{104}$ There is little salience to an improved safety record that can be demonstrated only by statistical comparisons over several years. But, the agency head's career could be ruined if shortly after changing airplane safety regulation a spate of crashes nonetheless occurs. When there is a strong perception that a problem already exists, however, an agency head may seek to act in order to claim credit for addressing the problem. This is especially true when the problem is

101 Note, that to the extent that careerist agency head tenure is sufficiently long to allow them to reap rewards for agency achievement, they tend to head agencies that produce goods or provide services rather than setting policy. These agencies tend to be presented with the same sorts of decisions every day, and not to be presented with choices about whether to act to create policy or refrain from doing so. See WILSON, BUREAUCRACY, supra note 59, at 200-01.

102 WILSON, BUREAUCRACY, supra note 59, at 209.

103 Cf. Morris Fiorina, Congress: THE Keystone of the Washington ESTABLISHMENT 44 (1977) (describing many congressional delegations as attempts by legislators to take credit for helping constituents aggrieved by agency decisions).

104 See EPSTEIN \& O'HALLORAN, supra note 14, at 8. 
sufficiently complex that the actual influence of the agency action on the problem cannot be evaluated, at least within the agency head's tenure. In short, while political agency heads have an incentive to act to attract media attention, the incentive will vary depending on the prospect for the agency head to take credit or blame for the outcome.

Agency heads appointed because of their professional qualifications generally do not have political aspirations. Instead, frequently they capitalize on their technical knowledge and connections gained as head of the agency by going to work for private entities when they step down from their official posts. Professional agency heads may take jobs as leaders of professional or industry groups or as lobbyists who, after the mandatory statutory period, represent stakeholders before the agency they once headed. ${ }^{105}$

The prospect of future private employment for agency heads, like that for staff members, raises the potential for capture. Incentives for regulated entities to promise an agency head a job upon her departure from the agency are greater than for staff members because agency heads can decide issues without obtaining consensus of others in the agency. The incentives for an agency head to allow herself to be captured, however, are not great. An agency head does not need the promise of a job by any particular stakeholder. The professional knowledge that qualified the agency head for her post to begin with, along with the connections and knowledge of the system that she subsequently develops as agency head, are too valuable for a stakeholder to forego the opportunity to hire her even if she refuses to do the stakeholder's bidding while in her position as agency head. In addition, her marketability depends on maintaining her professional reputation, and the risk of being seen as acting on behalf of a particular stakeholder may be too great a threat to this reputation to warrant the risk of capture.

Regardless of the likelihood of capture, a professional agency head can be expected to pursue aggressively a policy that members of her profession see as meritorious, and not to act on a policy that is seen as deleterious by that profession. Hence, the career incentives for a professional agency head to take action will depend on how the particular policy at issue relates to her professional background.

105 For example, William Kennard was appointed Chairman of the FCC by President Clinton after serving as counsel to the agency. He is now the Managing Director of the Global Communications and Media Group at the Carlyle Group, a private equity investment firm. See The Carlyle Group, http://www.carlyle.com/ team/ item 5739. html (last visited on Mar. 2, 2009). 


\section{Social Incentives}

Agency heads, like any other individuals, can be expected to desire that those with whom they work respect and appreciate their efforts. Each of three types of agency heads, however, is likely to look toward different constituencies from which to derive their sense of social belonging and self esteem.

Careerists come from the ranks of the agency, and are likely to attempt to act consistently with agency staff's perspective on a potential policy issue. Thus, on the one hand, a policy issue that culminates in a proposal from staff for action will be looked upon sympathetically by a careerist agency head. On the other hand, the desire for social acceptance is unlikely to push a careerist agency head to act on an issue that has not generated interest among her staff.

A politician agency head is apt to look for acceptance among political supporters, which will virtually always include the administration that appointed her. An agency head with political aspirations undoubtedly will see herself as part of the administration's team, and will seek approval from the President and high level White House advisors and cabinet members. This may influence political agency heads to behave differently from how they would behave if direct career incentives were the sole guide to whether to take action to address a policy issue. The administration may demand that an agency head put her neck on the line to allow the President to distance himself from the adoption of a policy in a situation that suggests that the proponent of a policy may take the blame if matters go awry. ${ }^{106}$ The White House may want the policy adopted to appease a powerful constituency, but may also understand that the policy will not play well with the public. By the same token, the administration may look to an agency head to remove a potential matter from the regulatory agenda in order to please core administrative constituents even when, by doing so, the agency head forfeits her ability to take credit for a popular outcome. In other words, the need for social acceptance can influence political agency heads either to act or to

106 For example, following the failed Bay of Pigs invasion of Cuba, President Kennedy is purported to have told CIA director Allen Dulles: "If we lived under a parliamentary system, I'd have to resign. We don't, so you have to." DAVID FrUM, THE Right MAN: THE SURPRISE PRESIDENCY OF GEORge W. BuSH 190 (2003). Another possible example of a CIA director taking one for the team stems from the George W. Bush administration blaming and firing CIA Director George Tenet for the miscalculation of Saddam Hussein's weapons of mass destruction. There is much speculation that the miscalculation occurred because the White House ignored contradictory evidence regarding the existence of such weapons provided by the CIA. See Joel R. Paul, The Bush Doctrine: Making or Breaking Customary International Law?, 27 HASTINGS INT'L \& COMP. L. REV. 457, 476-77 (2004). 
refrain from action. But this need is more likely to encourage agency action, because diffuse interest groups like the general public are likely to be more aware of matters that have attracted press attention, which usually means matters in which an agency has decided to act, than they are of matters involving inchoate potential outcomes.

A professional agency head may see herself as allied to particular organized stakeholder groups in a regulatory issue network because of her professional affiliation and background. She may seek to enhance her reputation among these allies. To the extent that an agency head has established a position favoring particular stakeholders and that position creates potential problems, she has an incentive to downplay the problems to avoid increased political dissatisfaction and oversight. 107 In other words, agency heads have a strong preference for autonomy, 108 which can best be satisfied by minimizing publicity about policy controversies. Because stakeholder allies of an agency head tend to be well informed about agency matters, however, the agency head is not going to be able to prevent damage to her reputation among organized interest groups by failing to act with the hope of hiding a potential policy issue. The incentive to keep a policy dispute quiet, therefore, is likely to discourage agency head action only when inaction placates organized interests to the detriment of diffuse stakeholders.

\section{Ideological Preferences}

At the federal level, the opportunity to influence policy is a major incentive for an agency head taking the job. ${ }^{109}$ Statutes give the agency head the formal authority to make the ultimate decision about what policies the agency adopts and implements. As noted earlier, some scholars have contended that the President controls agency policy. ${ }^{110}$ But pragmatically the

107 See Joseph A. Grundfest, Lobbying into Limbo: The Political Ecology of the Savings and Loan Crisis, 2 STAN. L. \& POL'Y REV. 25, 29 (1990) (describing how the Savings and Loan Industry convinced regulators to approve of accounting mechanisms "to conceal the depths of the problems" in the industry).

108 See WILSON, BUREAUCRACY, supra note 59, at 183 ("To a government executive an increase in the autonomy of his or her agency lowers the cost of organizational maintenance by minimizing the number of external stakeholders and bureaucratic rivals and maximizing the opportunity for agency operators to develop a cohesive sense of mission.").

109 WILSON, BUREAUCRACY, supra note 59, at 209. Note that at the state and local levels, because patronage is more prevalent than at the federal level, agency heads may be motivated more by the power to give friends and constituents jobs, than by the power to adopt policy.

110 See Kagan, supra note 10, at 2383-84; see also Croley, supra, note 72, at 870 71 (reporting that $\mathrm{OMB}$ review resulted in changes in a significant number of major rules 
President is not capable of controlling every aspect of agency policy, ${ }^{111}$ and even if he was, because the President will pay a price for replacing an uncooperative agency head, ${ }^{112}$ the reality is that agency heads generally have significant power to put in place their own policy preferences. As for agency staff, however, there are no systematic relationships between agency decisions to act and advancing the ideological preferences of an agency head.

\section{Summary of Agency Decision Makers' Personal Incentives to Act}

In those situations where staff dominates the agenda setting process-in particular situations in which policy is set by muddling through-staff members have an incentive to identify policy issues to increase their stature and reputation within the agency and with others in the issue networks within which they work. But agency staff members have a counterbalancing disincentive to identify such issues because identification ultimately decreases their ability to substitute leisure activities for work. Once a policy issue is identified as one an agency should seriously consider addressing, however, the balance between the incentives to garner recognition and to shirk changes. Shirking becomes less important because staff members are not able to shirk once the agency identifies an issue that their job responsibilities require them to address. In those situations where the agency head is likely to dominate the agenda setting process-when the agency attempts to set an agenda explicitly to further the agency mission, however that is defined-whether personal incentives favor or disfavor agency action depends on the goals of the agency head, and the particular circumstances she faces in deciding whether to regulate.

\section{PSYCHOLOGICAL INFLUENCES ON DECISIONS WHETHER TO ACT}

Thus far I have discussed rational motivations for agency heads and members of agency staff to prefer the agency to act or refrain from acting. Psychologists and more recently economists have recognized that individuals

under the Reagan, Bush I, and Clinton administrations). But cf. Lisa Schultz Bressman \& Michael P. Vandenbergh, Inside the Administrative State: A Critical Look at the Practice of Presidential Control, 105 MICH. L. REV. 47, 69 (2006) (concluding that "presidential control is more complex than scholars generally have acknowledged").

111 Mark Seidenfeld, A Big Picture Approach to Presidential Influence on Agency Policy Making, 80 IowA L. REV. 1, 13-19 (1994).

112 Peter Strauss, The Place of Agencies in Government: Separation of Powers and the Fourth Branch, 84 COLUM. L. REV. 573, 590 (1984) (asserting that a president will incur substantial political cost by discharging an administrator who has a public constituency). 
do not necessarily pursue their self-interest in an economically rational manner. ${ }^{113}$

\section{A. Decision-Making Heuristics and Biases}

Individuals may maximize utility at the margins, but they simplify decision-making tasks by using heuristics (rules of thumb) that allow them to make decisions within the complexity of the real world. ${ }^{14}$ For the most part, these rules of thumb stem from decision-making processes that have sufficed to allow individuals to make good decisions in a variety of day-to-day contexts. Sometimes, however, individuals apply these rules of thumb in contexts where they lead to systematic deviations from better decisions. ${ }^{115}$

Heuristic biases, however, are not inevitable. In the real world, an individual may be subject to societal influences and constraints that counteract the inappropriate use of a heuristic. Sometimes there may be a competing cognitive heuristic that counteracts the bias that results from use of the original heuristic in particular circumstances. This is especially true for agency decision making, because for many agency decisions individuals acting on behalf of the agency have to explain their proposed action and often have to get others working for the agency to agree with such action. ${ }^{116}$

Nonetheless, several systematic decision-making biases potentially affect the propensity of individuals within an agency to take action. This Article proceeds in this section by discussing these potential biases, and then in the next section addressing the extent to which the structure and procedures of agency decision making might ameliorate or exacerbate such biases.

113 See Simon, Models of Bounded RATIONALITY, supra note 24, at 291-94; George Lowenstien \& Richard H. Thaler, Intertemporal Choice, in RESEARCH ON JUDGMENT AND DECISION MAKING 365 (William M. Goldstein \& Robin M. Hogarth eds., 1997). This literature has recently been widely detailed and applied to various aspects of the law in a variety of settings. See Cass R. Sunstein, On the Psychology of Punishment, in THE LAW AND ECONOMICS OF IRRATIONAL BEHAVIOR 339 (Francesco Parisi \& Vernon L. Smith eds., 2005).

114 Amos Tversky \& Daniel Kahneman, Judgment Under Uncertainty: Heuristics and Biases, in JUDGMENT UNDER UNCERTAINTY: HeURISTICS AND BIASES 3, 3 (Daniel Kahneman et al. eds., 1982).

115 Id.; Scott Plous, The Psychology of Judgment ANd Decision Making 109 (1993).

116 See generally Jennifer S. Lerner \& Philip E. Tetlock, Accounting for the Effects of Accountability, 125 PSYCH. BULL. 255, 269-70 (1999) (reviewing the psychological literature on accountability and its effects in various settings). 


\section{Prospect Theory}

The first established heuristic bias that might affect an individual's propensity to act is Prospect theory. This bias refers to the influence on decision making of framing a decision as involving gains or losses from a reference point. ${ }^{117}$ Daniel Kahneman and Amos Tversky established that most individuals are risk averse with respect to gains but risk seekers with respect to losses. ${ }^{118}$ Also, individuals will weigh the prospect of losses more heavily in their decision than gains. ${ }^{119}$ These two aspects of prospect theory are known as loss aversion. ${ }^{120}$ In addition, individuals generally will place undue weight on very low probability outcomes of which they are aware. ${ }^{121}$

Loss aversion has often been demonstrated in contexts where the decision maker is asked to forfeit something from her endowment for something outside that endowment. ${ }^{122}$ Individuals, it turns out, do not like to give up items that they have come to see as theirs. This endowment effect is so pervasive that one can show that individuals who are given a coffee mug value it more highly than those who are not given the mug as soon as the recipients of the mug conceptualize it as theirs (i.e., include it in their endowment). ${ }^{123}$ Loss aversion, however, has now been demonstrated even in experimental situations in which decision makers consider actions that do not affect their personal endowments. ${ }^{124}$ Hence, it may influence decisions of

117 For a general introduction to prospect theory, see Daniel Kahneman \& Amos Tversky, Prospect theory: An Analysis of Decision Under Risk, 47 ECONOMETRICA 263, 263 (1979) [hereinafter Khaneman \& Tversky, Prospect theory].

118 Id. at 277-79; Amos Tversky \& Daniel Kahneman, Advances in Prospect theory: Cumulative Representation of Uncertainty, 5 J. RISK \& UNCERTAINTY 297, 306 (1992).

119 Khaneman \& Tversky, Prospect theory, supra note 117, at 279.

${ }^{120} \mathrm{Id}$.

121 Id. at $280-83$.

122 See, e.g., Daniel Kahneman et al., Anomalies: The Endowment Effect, Loss Aversion, and the Status Quo Bias, 5 J. ECON. PERSP. 193, 194, 196 (1991); Daniel Kahneman et al., Experimental Tests of the Endowment Effect and the Coase Theorem, 98 J. POL. ECON. 1325, 1328 (1990) [hereinafter Kahneman et al., Experimental Tests].

123 Kahneman et al., Experimental Tests, supra note 122, at 1328-33.

124 Michael J. Roszkowski \& Glenn E. Snelbecker, 19 J. BEHAV. ECON. 237, 245 (1990) (finding that framing affects financial planners' decisions about their clients' investments, but also that such planners would engage in less risky investments with their clients' money than their own); see also, e.g., Amos Tversky \& Daniel Kahneman, The Framing of Decisions and the Psychology of Choice, 211 SCIENCE 453, 453 (1981) (illustrating prospect theory using a problem asking participants to choose between programs that will save lives generally). 
agency personnel who are responsible for determining the trade off between private stakeholders' potential losses and gains.

Prospect theory predicts a bias against agency action when the agency faces a choice between imposing certain losses to avoid uncertain ones or to create the potential for uncertain gains. For example, prospect theory is consistent with the FAA failing to address the potential for fires on airplanes because preventative regulation would impose a certain and immediate cost but promise only future and uncertain avoidance of costly accidents. Conversely, prospect theory predicts a bias in favor of agency action that creates certain gains while forfeiting the possibility of uncertain gains or the avoidance of uncertain losses. Thus, prospect theory would explain an agency setting pollution control standards based on proven technology rather than on more experimental technology. Use of proven technology creates certain benefits and forfeits the uncertain promise of greater pollution reduction under as yet untested technology.

Experiments further indicate that whether people will view an outcome as a gain or a loss depends on how the decision is framed-that is, the reference point from which the decision maker will measure gains or losses may be manipulated. ${ }^{125}$ The manipulability of this reference point counsels that one be cautious before using prospect theory to predict a decision maker's propensity to act. To the extent that a stakeholder in a matter that could invoke agency action can establish its preferred reference point, framing can alter the likelihood that the agency will take action in response to a perceived problem. For example, in our pollution reduction example above, if individuals conceptualized levels of pollution as already incorporating expected future reductions from experimental technologies, substituting standards based on proven technologies for technology forcing standards would be seen as imposing certain losses instead of uncertain ones. Prospect theory predicts that individuals would be reticent to make this trade.

\section{The Status Quo Bias}

A second heuristic bias that is potentially relevant to a decision maker's propensity to act is the status quo bias. This bias refers to individuals' tendency to maintain the status quo rather than engage in behavior that leads to change in the state of the world. ${ }^{126}$ Very frequently, action is required to change the status quo, and one might suspect that the status quo bias is really

125 Daniel Kahneman \& Amos Tversky, Choices, Values, and Frames, 39 AM. PSYCH. 341, 343-44 (1984).

126 For a general overview of the status quo bias, see generally William Samuelson \& Richard Zeckhauser, Status Quo Bias in Decision Making, 1 J. RISK \& UNCERTAINTY 7 (1988). 
a direct bias against action. It is crucial to recognize that the status quo bias is not the same as a bias against action, and may in fact encourage action in some situations. Psychologists have created experimental scenarios in which inaction leads to changed outcomes and hence action is necessary to maintain the status quo. ${ }^{127}$ In such scenarios, the status quo bias would cause individuals to take action to maintain the status quo.

There are at least two underlying explanations for the status quo bias. The first is loss aversion. In many situations, an individual faces a choice between doing nothing, which will preserve the status quo, and expending resources now for the potential of uncertain gains down the road. As noted earlier, loss aversion in that situation will encourage the individual not to act, which preserves the status quo. ${ }^{128}$ In other contexts, however, the status quo may include uncertain possibilities of future gain, and the decision maker must choose between maintaining these uncertain prospects or cashing them in for a sum certain. In that situation, loss aversion would give rise to a bias against the status quo. Hence, loss aversion is best considered as a bias independent of the propensity of individuals to maintain the status quo.

The second explanation, which provides a more consistent bias toward the status quo, stems from people's aversion to having to make difficult decisions. If the choice facing an individual involves trading off one important value for another, or forces the individual to choose between two outcomes both of which she perceives to be negative, then she will experience discomfort when making the decision. The individual may try to relieve this discomfort by looking for means to avoid involving herself deeply in the decision (perhaps minimizing feelings of responsibility by such avoidance). ${ }^{129}$ One such means is to stick with the status quo when it is a focal point or reference point for the decision maker. ${ }^{130}$ The idea is that the

127 Ilana Ritov \& Jonathan Baron, Status-Quo and Omission Biases, 5 J. RISK \& UNCERTAINTY 49, 49-50 (1992).

128 Id. at 49.

129 This discomfort stems from what psychologists describe as cognitive dissonance. LeON Festinger, A TheORY of Cognitive Dissonance 1-3 (Stanford University Press 1962) (1957). When individuals make decisions that involve discretion, cognitive dissonance will be aroused if the decision forces the individual to act inconsistently with his values or beliefs. Thus, dissonance will be aroused when a choice includes some traits that the decision maker considers negative and the foregone alternative include some traits the decision maker considers positive. Eddie HarmonJones \& Judson Mills, an Introduction, in COGNITIVE Dissonance: Progress ON A Pivotal Theory IN Social Psychology 1, 5-6 (Eddie Harmon-Jones \& Judson Mills eds., 1999). One way an individual may strive to reduce such dissonance is by decreasing their perception of the importance of the decision. FESTINGER, supra, at 22.

$130 \mathrm{Cf}$. John C. Harsanyi \& Reinhard Selten, a General Theory of EQUILIBRIUM SELECTION IN GAMES 275-368 (1988) (discussing basis for choice between 
decision maker simply picks the existing state of affairs to avoid having to agonize over the decision. ${ }^{131}$ Thus, according to this explanation, the status quo bias does not stem from anticipation of future regret about the outcome of a decision, but rather from the angst the decision maker feels at the time she makes the decision. 132

In the context of an agency setting regulatory policy, the status quo bias does not consistently favor either action or inaction. On the one hand, agencies frequently face decisions that have the effect of changing the state of the world when they are asked to respond to an existing problem. Facing such a decision, the status quo bias would discourage agency action. On the other hand, agencies often address problems that, left unresolved, threaten to change the state of the world for the worse. In such cases an agency decision maker may define her role as maintaining the status quo. For those decisions, the status quo bias could encourage agency action.

\section{Omission Bias}

The third cognitive bias that might affect an individual's likelihood of taking action in response to a perceived problem is the omission bias. It is the bias most directly relevant to agency decisions on whether to act in response to a perceived problem because the omission bias refers to an individual's non-rational propensity to refrain from acting. ${ }^{133}$ This propensity is nonrational when the expected outcome from not acting is inferior to the expected outcome from taking action. Psychologists studying the omission bias use as a prime example experiments showing that many individuals say they would decline to vaccinate their children against an imminent epidemic

multiple equilibria in game theory); R. DUNCAN LUCE \& HowARD RAIFFA, GAMES AND DECISIONS 126-55 (1957) (same).

131 See Christopher J. Anderson, The Psychology of Doing Nothing: Forms of Decision Avoidance Result from Reason and Emotion, 129 PSYCH. BULL. 139, 143-44 (2003).

132 But see id. at 144 (noting that there is some evidence of emotional outcomes affecting the status quo bias). Note that decision makers may have other focal points than the status quo, and may exhibit a bias toward these focal points. For example, psychologists have shown that individuals faced with a choice of alternatives about which they know little or cannot choose will often pick the first alternative on the list. Douglas K. Detterman, Distinctiveness and Serial Position in Short-Term Memory for Lifted Weights, 87 AM. J. PSYCHOL. 95, 96 (1974). And my son, when he was four, used the "eeny, meeny, miny, mo" principle for choosing between alternatives. Both of these mechanisms, like the choice of status quo, reduce the angst created by the decisionmaking process.

133 Ilana Ritov \& Jonathan Baron, Outcome Knowledge, Regret, and Omission Bias, 64 Org. Behav. \& Hum. Decision Processes 119, 119 (1995). 
because of the risk the vaccine might kill their children even if the risk of death from the vaccine is less than that from the epidemic. ${ }^{134}$

The omission bias occurs because people attribute the cause of outcomes more strongly with action than inaction, and therefore they feel more responsibility for outcomes that follow from action. ${ }^{135}$ Hence, when faced with a choice of two negative outcomes, people choose the outcome that results from inaction, even if that is worse, thereby avoiding regret or blame that may accompany the better but still negative outcome that would result from action. ${ }^{136}$

The mechanism responsible for the omission bias suggests that there should be an opposite bias toward action when an individual is faced with outcomes that they view as positive, and recently, several psychologists have demonstrated this "action bias." 137 This mechanism also suggests that the strength of both the omission bias and action bias depends on factors that make the negative or positive aspects of the outcomes more salient. ${ }^{138}$ Salience of positive and negative aspects of outcomes could depend on whether the outcome represents a change from an accepted reference point such as the status quo (which is more salient) rather than a maintenance of the status quo (less salient); whether the outcome compromises protected values-values that individuals express reluctance to trade off against other values (more salient) - rather than trade-offs that individuals readily make in day-to-day contexts (less salient); whether the outcome is certain (more salient) rather than uncertain (less salient); or whether the outcome was prompted by abnormal (more salient) or normal (less salient) factors.

Demonstration of the omission bias is older than of the action bias, and generally accepted in the literature; the action bias is not as well known. ${ }^{139}$ One explanation for the prevalence of the omission bias over an action bias is

134 llana Ritov \& Jonathan Baron, Reluctance to Vaccinate: Omission Bias and Ambiguity, 3 BeHAV. DECISION MAKING 263, 275 (1990).

135 E.g., Daniel Kahneman \& Dale T. Miller, Norm Theory: Comparing Reality to Its Alternatives, 93 PsYCHOL. REV. 136, 145 (1986); see also Spranca et al., Omission and Commission in Judgment and Choice, 27 J. EXPERIMENTAL SOC. PSYCHOL. 76, 85-86 (1991) (mock jurors awarded larger sums of money to victims of commission than victims equally harmed by omission).

136 See Marcel Zeelenberg, Joop van der Pligt \& Nanne K. De Vries, Attributions of Responsibility and Affective Reactions to Decision Outcomes, 104 ACTA PsYCHOLOGICA 303, 304-05 (2000).

${ }^{137}$ E.g., Anthony Patt \& Richard Zeckhauser, Action Bias and Environmental Decisions, 21 J. RISK \& UNCERTAINTY 45, 55-59 (2000).

138 Id. at 46.

139 Jonathan Baron \& Ilana Ritov, Omission Bias, Individual Differences, and Normality, 94 ORG. BeHAv. \& HUM. DeCISION PROCESSES 74, 74 (2004). 
the psychological notion of loss aversion that I already described. ${ }^{140}$ Generally people weight the prospect of a loss more heavily in their decisionmaking calculus than they do the prospect of gain. ${ }^{141}$ Hence, when faced with the prospect of action that would cause loss along one criterion for evaluating outcomes (e.g., money) and a gain along another criterion (e.g., risk of death), the negative feeling of responsibility for the loss may outweigh the positive feeling of responsibility for the gain.

Some experiments, however, question whether the omission bias is more prevalent than an action bias or even if it is real. ${ }^{142}$ One study has found that the omission bias is not evident when experimental survey instruments present symmetrical options for action and inaction. ${ }^{143}$ Another has found that when survey instruments present symmetrical options, that loss aversion swamps action and omission biases for individuals who do not hold many protected values, but that individuals who do hold many protected values have a propensity to take action whether or not the outcomes are framed as positive or negative, certain or uncertain. ${ }^{144}$ Thus, the prevalence and strengths of both the omission and action biases seem to depend on many variables. At a minimum, they depend on whether an action is seen as posing downside risks rather than upside opportunities, as well as on individual differences in the extent to which the decision maker sees the action as preserving protected values and, as I shall discuss below, on the social role of the decision maker.

\section{B. Influence of Social Role on the Propensity to Act}

The social roles that individuals perceive themselves as filling greatly influence how they behave. Social roles are means to "describe how ... social interactions become routinized into shared normative and behavioral expectations."145 Psychologists derive their concept of social role from social identity theory.

${ }^{140}$ See supra notes $117-25$ and accompanying text.

141 Khaneman \& Tversky, Prospect theory, supra note 117, at 279.

142 Terry Connolly \& Jochen Reb, Omission Bias in Vaccination Decisions: Where's the "Omission"? Where's the "Bias"?, 91 ORG. BEHAV. \& HUM. DECISION PROCESSES 186, 186-87 (2003).

143 Id. at 197.

144 Carmen Tanner \& Douglas L. Medin, Protected Values: No Omission Bias and No Framing Effects, 11 PSYCHONOMIC BULL. \& REV. 185, 189 (2004).

145 Kristen Renwick Munroe, James Hankin \& Renée Bukovchik Van Vechten, The Psychological Foundations of Identity Politics, 3 ANN. REV. POL. SCI. 419, 426 (2000). 


\section{Social Identity and Social Role}

Individuals define themselves in terms of personal and social identity. Personal identity refers to how people think of themselves as different from others, and social identity as how they think of themselves as similar to others. A person creates a social identity by characterizing herself as fitting within various social schemas or categories, for example: mother, lawyer, friend, cook, as well as a host of other categories. By nature, these schemas compare the individual to others who fall within the same categories. These schemas can be considered the social roles that a person ascribes to herself. Social identity thus can be viewed as internalization of social roles corresponding to the social situation of the individual. ${ }^{146}$

Individuals conform their behavior to their perceived social roles for several reasons. Individuals have a basic social need to belong to groups. ${ }^{147}$ They define their senses of self in terms of the social groups to which they strive to be part. ${ }^{148}$ People behave consistently with socially defined norms to attain social acceptance by those groups that define their senses of self, 149 thereby avoiding the negative physical and psychological effects of rejection. ${ }^{150}$ In addition, individuals define their perception of reality, including their perception of who they are, in part by reference to the social norms of members of these groups. ${ }^{151}$ Thus, an individual may reinforce her

146 Sheldon Stryker, Identity Theory: Developments and Extensions, in SELF AND IDENTITY: PsYchosocial PeRspectives 89, 90 (Krysia Yardley \& Terry Honess eds., 1987).

${ }^{147}$ Roy F. Baumeister \& Mark R. Leary, The Need to Belong: Desire for Interpersonal Attachments as a Fundamental Human Motivation, 117 PSYCHOL. BULL. 497, 499 (1995).

${ }^{148}$ An individual creates her social identity by internalizing into her self-concept the roles corresponding to membership in the groups to which she wishes to belong. Peter J. Burke \& Judy C. Tully, The Measurement of Role Identity, 55 SOC. FORCES 881, 883 (1977).

149 Charles S. Carver \& Michael F. Scheier, Attention and SelfRegulation: A CONTROL-ThEORY APPROACH to Human BeHAVIOR 123-26 (1981); Roy F. Baumeister et al., Social Exclusion Impairs Self Regulation, 88 J. PERSONALITY \& Soc. Psychol. 589, 590 (2005); Roy F. Baumeister et al., Ego Depletion: Is the Active Self a Limited Resource?, 74 J. PERSONALITY \& SOC. PSYCHOL. 1252, 1253 (1998).

${ }^{150}$ Roy F. Baumeister et al., Effects of Social Exclusion on Cognitive Processes: Anticipated Aloneness Reduces Intelligent Thought, 83 J. PERSONALITY \& SOC. PSYCHOL. 817, 825 (2002); John T. Cacioppo et al., The Anatomy of Loneliness, 12 CURRENT DiRECTIONS IN PSYCHOL. SCI. 71, 74 (2003).

151 Solomon E. Asch, Studies of Independence and Conformity: I. A Minority of One Against a Unanimous Majority, 70 PSYCHOL. MONOGRAPHS 1, 70 (1956). Group cohesiveness increases pressure on members toward compliance with group norms. See 
sense of self by acting as she sees other group members act-that is, by engaging in role appropriate behavior.

In other words, identity motivates particular kinds of action that will result in social confirmation of the identity so that an individual will take actions reinforcing the social expectations attached to the role. ${ }^{152}$ Of particular relevance to the influence of social roles on agency action, leaders are motivated to behave in ways indicative of leadership ability, continually affirming to group members that they possess appropriate leadership qualities. ${ }^{153}$ When different social roles demand different behavioral responses, the individual may react to the role that is most salient in the particular circumstances in which she finds herself. ${ }^{154}$ Or, relatedly, individuals may have "situated identities," which they use to define themselves and their relationship to others according to expected behaviors for that particular context.

Expected behaviors that correspond to social roles may involve a particular way of perceiving and processing information; in addition, they may involve particular acts. Thus, social roles can result not only in simple role appropriate behavior, they can also lead to "biases" in how individuals process and react to information. An individual can deviate from what otherwise would appear to optimize her satisfaction because of the need to maintain her sense of identity. ${ }^{155}$

\section{An Official's Job as a Social Role that Affects the Propensity to Act}

One type of social role that many individuals incorporate into their definition of self is their job. In the appropriate context, I think of myself as a law professor. Agency staff members are apt to define their professional selves in terms of their titles and responsibilities within their office, and agency heads might see themselves as being ultimately responsible for every potential decision within the jurisdiction of the agency. The more salient the official's identity as a member of the agency, the more sensitive the official will be to opportunities for behavior confirming that identity ${ }^{156}$ Therefore, a

Harry Prapavessis \& Albert V. Carron, Sacrifice, Cohesion, and Conformity to Norms in Sport Teams, 1 Group DyNAMICS: THEORY, RES. \& PrAC. 231, 232 (1997).

152 Peter J. Burke \& Donald C. Reitzes, An Identity Theory Approach to Commitment, 54 SOC. PSYCHOL. Q. 239, 242 (1991).

153 Mark R. Leary, R.B. Robertson, B.D. Barnes \& R.S. Miller, Self-Presentations of Small Group Leaders: Effects of Role Requirements and Leadership Orientation, $51 \mathrm{~J}$. PERSONALITY \& SOC. PSYCHOL. 742, 747 (1986).

154 Stryker, supra note 146 , at $89,94-98$.

155 Munroe et al., supra note 145 , at 425.

156 Stryker, supra note 146 , at 95. 
person whose job assigns her responsibility for a policy decision may act differently than one who evaluates the decision solely in terms of her personal interests, and certainly differently from an objective observer asked whether he thinks action is appropriate. ${ }^{157}$

Social roles affect officials' propensity to act by constraining the conduct of officials to comport with expectations consonant with their official roles. In particular, once a potential problem within an individual's official authority is identified, the individual is likely to see his role as calling for action to try to cure the problem. ${ }^{158}$ In addition, a person's role as an official responsible for matters within his jurisdiction can alter the causal attribution made by the individual as well as by other observers. Attribution and role theory connect because both address how individuals create their identities. Individuals attribute causal consequences in a manner that allows them to maintain their existing identity as well as to take on new desirable aspects of their identity. ${ }^{159}$ An individual who defines himself as responsible for outcomes from problems that are within his job's domain of action is more likely to be seen, and to see himself, as the cause of outcomes from those events, whether or not the individual acts or declines to act in response to the problem. Moreover, they are especially apt to act in response to the problem when action is the role appropriate norm, whether or not action is the optimal behavior. ${ }^{160}$

\section{Social Role Theory and the Omission and Action Biases}

Social role theory was mentioned as a possible explanation for why, in one study, individuals exhibited an action bias when asked to make decisions that involved protected values regardless of whether the bias involved decisions framed in terms of positive outcomes or negative outcomes, and regardless of whether action led to certain or uncertain outcomes. ${ }^{161}$ In that study, subjects were told that they had the authority to take action to solve

157 See id. at $95-96$.

158 This is consistent with a study of elite soccer goalies, who generally commit to dive to one side or the other when faced with a penalty kick, even though evidence shows that their best strategy is to remain in the middle of the goal. Michael Bar-Eli et al., Action Bias Among Elite Soccer Goalkeepers: The Case of Penalty Kicks, 28 J. ECON. PSYCHOL. 606, 615-16 (2007).

159 See Philip E. Tetlock, Toward an Intuitive Politician Model of Attribution Processes, in THE SELF AND SOCIAL LIFE 203, 212 (Barry R. Schlenker ed., 1985).

160 See Bar-Eli, supra note 158 , at 615 (explaining that, according to norm theory, a person will feel more strongly about a consequence when he acts inconsistent with the norm for his relevant social role).

161 Tanner \& Medin, supra note 144, at 189. 
environmental problems. ${ }^{162}$ Individuals in that social role chose to act even when prospect theory and the omission bias would have predicted that they would refrain from action. ${ }^{163}$ The authors conjectured that when one is put in the role of a person with authority to do something about an issue involving fundamental values, that person will feel a moral compulsion to act. ${ }^{164}$ If that is the explanation for the results of this study, it would indicate that the impact of social role can overpower the affect of cognitive biases at least in contexts triggering strong emotional responses from individuals. Moreover, agency officials frequently find themselves in workplace roles in which they have authority to take action that involves what most individuals consider protected values. Hence, the literature on the action bias, while nascent, supports that this bias is more likely to come into play for decisions by these officials than is the omission bias.

\section{AgenCy Structures, Procedures AND OVERSEers}

Thus far, this article has explored the individual incentives and psychological influences that might prompt agency decision makers either to address a policy issue or to refrain from acting on that issue. Agency action, however, occurs after input of many individuals who interact within a preset structure, following administrative procedures and subject to oversight by the political and judicial branches. Agency structure, procedure and oversight have the potential to change the dynamic of agency decision making and thereby alter an agency's likelihood of addressing any particular regulatory issue it confronts.

\section{A. Agency Overseers}

Although I limit my consideration in this article to internal agency decision-making processes, and therefore do not investigate constraints imposed at the institutional level by oversight of agency action, such oversight influences the incentives facing individuals within agencies and the likelihood that they will succumb to cognitive decision-making biases. Direct

162 Id. at 187.

$163 \mathrm{Id}$. at 189.

164 Id. A person whose social role makes them responsible for an outcome may feel a need to act even when the action does not involve moral consequences. Thus, survey data suggest that soccer goalies feel responsible for failing to stop goals on penalty kicks, see Bar-Eli, supra note 158 , at 615 , but still almost always dive to one side or the other, see id. at 613 , even though attribution theory would predict that such action increases their sense of causal responsibility for the negative outcome. See supra note 135 and accompanying text. 
oversight of agency action generally is done by the named branches of government and breaks down into political review and judicial review. ${ }^{165}$ Because the incentives created by political and judicial review differ in fundamental ways, it is best to consider the influence of each on agency decision makers separately.

\section{Political review by Congress and the President}

Both the White House and Capitol Hill review agency policy. Political review is backed up by threats that the political branches will subject agency heads and staff to time consuming hearings that can harm individual decision makers' reputations, will discontinue appropriations for agency programs, and in extreme cases will directly reverse agency policies. ${ }^{166}$ Review by either branch tends to focus on whether the policy adopted by the agency accords with preferences of the reviewing institution. According to the psychology of accountability, the most predictable reaction of agency decision makers to such outcome review will simply be to attempt to act in accordance with the preferences of its overseers. ${ }^{167}$ Preferences of those on Capitol Hill and the White House will vary with the precise issue before the agency in no systematic manner. Whether Congress or the President prefers that the agency act will reflect the politics of that issue. In fact, especially in times of divided government, Congress and the President may compete with each other to maintain control over agency decision making, in the process often attempting to steer agencies in different directions. ${ }^{168}$ Hence, political review is unlikely systematically to drive agencies towards or away from action aćross the issues potentially subject to agency regulation.

One exception to the lack of systematic influence of political review on an agency's propensity to act may derive from mandatory OMB review both of an agency's regulatory plan and of the agency's cost-benefit analysis for

165 In limiting my discussion of review to that by the government, I do not mean to ignore the fact that private entities such as the press and interest groups will review and react to agency action. But their reaction will be carried out either by bringing their concerns to a branch of government-the President, Congress, or the courts-or by making their concerns known directly to the agency, which will have a bearing on the agency propensity to act via the internal structures and procedures of the agency.

166 Barry R. Weingast, Caught in the Middle: The President, Congress, and the Political-Bureaucratic System, in THE EXECUTIVE BRANCH, supra note 54, at 329-31.

167 See Seidenfeld, supra note 89, at 1064-65.

168 See Sidney A. Shapiro, Political Oversight and the Deterioration of Regulatory Policy, 46 ADMIN. L. REV. 1, 4-5 (1994). 
any major rule. ${ }^{169}$ With respect to the regulatory plan, every agency is required to include in its plan "the most important significant regulatory actions that the agency reasonably expects to issue in proposed or final form in that fiscal year or thereafter."170 The regulatory plan thus gives the Office of Information and Regulatory Affairs (OIRA) within OMB a heads-up and the opportunity to influence agency rulemaking from its earliest stages. ${ }^{171}$ The requirement that agencies place prospective significant regulations in the agency plan adds to the procedures for rulemaking, which discourages action, most significantly action that the White House or personnel in (OIRA) do not support. ${ }^{172}$

In addition to creating a regulatory plan, agencies must prepare a costbenefit analysis of all significant proposed and final regulations and submit these regulations with the accompanying analyses to OIRA for review. ${ }^{173}$

169 See Exec. Order No. 12,866, 3 C.F.R. 638 (1993), reprinted in 5 U.S.C. $\$ 601$ app. at $638-42(2000)$. The details of OMB oversight and its relation to agency rulemaking may soon change because President Obama has requested the head of OMB to recommend changes to Executive Order 12,866 within 100 days of January 30, 2009. President's Memorandum for the Heads of Executive Departments and Agencies on Regulatory Review, 74 Fed. Reg. 5977 (Feb. 3, 2009) (Presidential Memorandum on Regulatory Review).

${ }^{170} \mathrm{Id}$. at $\S(4)(\mathrm{c})$.

171 President George W. Bush strengthened the influence of OMB by mandating that an agency could not proceed with a major rule unless the Office of Information and Regulatory Affairs within OMB signed off on the conclusion that the benefits of the rule will exceed its costs. Exec. Order No. 13,422, 72 Fed. Reg. 2763 (Jan. 23, 2007). He also added to the provisions on the agency regulatory plan that an agency may not commence a rulemaking or include a rulemaking in its regulatory plan without the approval of the agency Regulatory Policy Officer (RPO). Id. at $\S(4)(b)$. In addition, President Bush specified that each agency RPO must be a presidential appointee within the agency, and changed responsibility within the agency so that the RPO no longer reports to the agency head, but rather seems to be accountable to the Office of Management and Budget (OMB). Id. at $\S(5)(\mathrm{b})$. President Obama, however, repealed Executive Order 13,422 shortly after taking office. Exec. Order No. 13,497, 74 Fed. Reg. 6113 (Feb. 4, 2009). Obama also issued a memorandum calling for a new executive order to replace the specification of the relationship of OIRA to agencies and criteria for agency rulemaking that currently is laid out in Executive Order 12,866. 74 Fed. Reg. 5977 (Feb. 3, 2009).

172 See Seidenfeld, supra note 89, at 1074-75; see also Bressman \& Vandenbergh, supra note 110, at 75 (noting that independence of OIRA desk officers' judgment from the preferences of Administrator and the President is problematic); Seidenfeld, supra note 111 , at 18 (describing how the agency costs of the White House monitoring OIRA desk officers undermine the President's ability to keep agencies true to his regulatory vision).

173 Exec. Order No. 12,866, supra note 169, at § 6(a)(3)(B). President George W. Bush had added a requirement that agencies identify and submit significant guidance documents for review by OIRA. This adds costs to what had been a fairly low-cost mechanism to announce the agencies intentions with respect to interpretations of statutes 
This is an onerous requirement that significantly adds to the cost of rulemaking. ${ }^{174}$ Moreover, OIRA is staffed predominantly by policy analysts who are trained to look for costs in proposed actions and the office has an institutional commitment to keeping regulatory costs in check. Thus, agencies seeking to placate OIRA will be tempted to refrain from regulating by issuing a major rule when the agency will not be able to determine conclusively that the benefits of the rule exceed its costs, especially when the agency knows that those costs will be large. In addition, agencies may shy away from acting by issuing major rules to resolve regulatory problems because of the burden of having to prepare a cost-benefit analysis for OIRA to review.

\section{Judicial Review}

Agencies must justify their actions as being within their legal authority and not being arbitrary and capricious. ${ }^{175}$ This requires that they explain their actions in light of the statutes that give them their powers, and the circumstances that prompt those actions. In essence, an agency must justify its action in a manner that persuades judges assigned to the case on review that the agency has carefully considered all factors that the judges find relevant to the agency decision. ${ }^{176}$ The specific considerations that an individual judge might deem relevant to the legality or wisdom of an action derive, to some extent, from that judge's perspective regarding that statute and even how the regulatory system should work. ${ }^{177}$ Thus, a judge might find relevant such considerations as the relative costs and benefits of an action,

and regulations, or policies to implement statutes or regulations. See Exec. Order No. 13,422 , supra note 171 , at $\S 7$, repealed by Exec. Order 13,497, supra note 171 . For a detailed description of OMB oversight of regulation, see Croley, supra note 72, at 84143.

${ }^{174}$ Even if the President had not ordered agencies to prepare cost-benefit analyses, it is not certain that agencies might otherwise have not prepared such analyses for significant regulation in order to shield themselves from reversal under the far-reaching and uncertain bounds of judicial review of agency policymaking. See infra notes 175-83 and accompanying text.

1755 U.S.C. $\S \S 706(2)(A), 706(2)(C)(2000)$.

176 See Thomas A. McGarity, Some Thoughts On "Deossifying" the Rulemaking Process, 41 DUKE L.J. 1385, 1400-01 (1992); Seidenfeld, supra note 3, at 491-92.

177 See Pierce, supra note 2, at 300; cf. Patricia M. Wald, Some Thoughts on Judging as Gleaned from One Hundred Years of the Harvard Law Review and Other Great Books, 100 HARV. L. REV. 887, 891 (1987) (arguing that the different voting records of Republican and Democratic judges reflect differences in the "personalit[ies] and life experiences that lead the judge to vote Democratic or Republican" rather than explicit consideration of ideology). 
the extent to which the action disrupts reasonable expectations of regulated entities, whether the benefits of the action go to groups who the judge considers to be the intended beneficiary of the regulatory scheme, and whether the action benefits those the judge considers most in need of governmental protections. In addition, judges will consider evidence of the reliability and veracity of information, assumptions and predictions that the agency relies on to justify its action. Judges will be more or less accepting of the reliability and veracity of such data depending on whether they are more or less individually inclined to favor the outcome that results from the agency action. ${ }^{178}$ In short, factors that a judge on the reviewing court likely will find relevant to his determination of the acceptability of the agency action will depend significantly on the identity of the reviewing judge. The psychology of accountability suggests that, because agencies do not know in advance the identities of judges who will review their actions, they must address all plausible relevant considerations when justifying their decisions. ${ }^{179}$

Judicial review affects an agency's propensity to act essentially in two ways. First, it raises the cost of an agency changing policy or, in other words, it raises the price that the agency faces for action. This price rise will discourage agency action overall. But, as I have discussed earlier, an agency staff member has an incentive to push the agency to change policy for matters within his work responsibilities, because action enables the staff member to improve his reputation and thereby to gain consideration for promotion within the agency. ${ }^{180}$ Thus, for items potentially on the agency policy agenda on which staff is likely to have greater impact than the agency head, such as those resulting from an incremental policy setting process, or technical issues that come out of a comprehensive purposive approach to regulation, the increased price of regulatory action may be justified as a means of offsetting agency staff incentives to encourage action even when the public interest does not warrant it.

The cost imposed on the agency because of judicial review will vary from one policy issue to the next. Given the nature of arbitrary and capricious review, judicial review will especially discourage action when the

178 See Pierce, supra note 2, at 301-02 (asserting that judges on the D.C. Circuit appointed by a Democratic President are more likely to reverse an agency when an individual petitions for review, and judges appointed by a Republican President are more likely to reverse when the petitioner is a business interest). But cf. Harry T. Edwards, Public Misperceptions Concerning the "Politics" of Judging: Dispelling Some Myths About the D.C. Circuit, 56 U. COLO. L. REV. 619, 633 (1985) (using reversal rates for D.C. Circuit cases during the 1983-1984 term to argue that judges' politics and ideology matters to their votes only in cases involving "ultimate values," a very small percentage of cases the court hears).

179 See Seidenfeld, supra note 87, at 516-17.

180 See supra notes 58-59 and accompanying text. 
agency is uncertain that it can persuade individuals with different political and ideological perspectives that its action is justified. Thus, judicial review is especially likely to discourage agencies from adopting policies that cannot easily be justified on a non-political / instrumental basis. To some extent, such policies correlate with those the agency should not be adopting in its discretion, because agency discretion is most appropriately exercised when the decision is not purely political. ${ }^{181}$

In addition to the incentive that judicial review provides to staff members and agency heads as rational utility maximizers, review also affects the various psychological biases that can affect decision makers' propensities to act. Generally, one can expect judicial review to ameliorate biases that result from decision makers taking cognitive shortcuts. ${ }^{182}$ Thus, judicial review should reduce the impact of framing biases, because it encourages decision makers to consider various baselines for framing their analyses. Similarly, review should reduce the status quo bias even though it will not reduce the angst created by having to make a decision, because judicial review demands thorough analysis that is likely to decrease the number of situations where a decision maker remains relatively indifferent between a change in outcomes and the status quo. For biases that reflect an interaction between social and cognitive mechanisms, the affect of judicial review generally is more nuanced. ${ }^{183}$ Thus, on the one hand, judicial review might mollify omission and action biases because it encourages a decision maker to engage in careful analysis that will reveal whether action is socially optimal. On the other hand, judicial review might focus a decision maker on the increased likelihood that she will be blamed or credited more for outcomes that result from her actions than for outcomes that result from inaction, and might therefore exacerbate omission and action biases.

\section{B. Agency Structures and Procedures}

The need for an agency to comply with procedural requirements adds costs to the decision-making process, and in that sense, like judicial review,

181 See Peter Strauss, Overseer, or "The Decider"? The President in Administrative Law, 75 GEO. WASH. L. REV. 696, 711 (stating that "political preferences simpliciter will not suffice to support decisions subject to judicial review"). Thus, in Hazardous Waste Treatment Council v. EPA, 886 F.2d 355 (D.C. Cir. 1989), the D.C. Circuit rejected as inadequate an agency explanation of its decision as being the best response to comments by members of Congress. Id. at 365 . This is not to deny that agencies are expected to be influenced by politics, but political influence is to be moderated by expert knowledge, experience, and the ability to justify decisions objectively. See Seidenfeld, supra note 74 , at $1548-49$.

182 Seidenfeld, supra note 87 , at 522.

183 Id. at 523. 
discourages agency action. In fact, in some instances, Congress or the President imposes procedures with the intent of discouraging action, or at least slowing it down sufficiently to allow constituents to register concerns about agency action with the political branches. ${ }^{184}$ Agencies, however, can create and change policies by any of several means, and each of these means employ different procedures and even different structures for the decisionmaking body. Hence, these different procedural requirements not only impose different costs, they also provide different incentives for those within the agency to advocate agency action, and thereby can affect agency propensities toward action. In this subsection, I first describe the various procedures and structures that attach to the different modes agencies might use to affect a policy change, and then analyze the potential impact of these procedures and structures on the propensity to act.

\section{Agency Decision-making Structures and Procedures}

As I already noted in discussing the players within agencies that affect decisions whether to act, as with any bureaucracy, such decisions reflect inputs from agency staff to an agency head responsible for the ultimate decision. ${ }^{185}$ The relative significance of staff versus the agency head varies, but in virtually every instance the staff at least filters the information and policy choices available to the agency head. In performing this function, staff may be organized into one of three basic structures.

When an agency proceeds by legislative rulemaking on a matter of known significance, a team structure is most often used to generate proposed policies and to hone final policies to reflect comments that the agency receives during the rulemaking. Staff input comes from a team of representatives from various offices within the agency whose expertise is helpful for making necessary factual predictions that affect the evaluation of the wisdom of adopting the rule. ${ }^{186}$ Essentially, staff input represents a consensus of those on the team; the team as a whole must support the

184 See McCubbins et al., Administrative Procedures, supra note 9, at 258-59 (noting the value to Congress of delaying and making public agency action); Weingast, supra note 166, at 322-25; Matthew D. McCubbins \& Thomas Schwartz, Congressional Oversight Overlooked: Police Patrols Versus Fire Alarms, 28 AM. J. PoL. SCI. 165, 166 (1984) (contending that rules Congress imposes on agencies serve to facilitate monitoring of agency action by constituents and reporting of problems with agency action to Congress).

185 See supra note 19 , and accompanying text.

186 See McGarity, supra note 87, at 86-88; Seidenfeld, supra note 87, at 527-28. 
information and recommendations given to the ultimate decision maker. ${ }^{187}$ Usually, the analyses and recommendations of such a team are circulated to heads of the various offices within the agency to make sure each office does not find anything egregiously problematic with them. ${ }^{188}$

When an agency uses more informal procedures to generate policy changes, such as when it issues a guidance document - - a general statement of agency policy or an interpretive rule ${ }^{189}$ - or an order that comes out of an informal adjudicatory proceeding, to make policy, ${ }^{190}$ staff input is more likely to come from a group comprised almost exclusively of members of a single office within the agency. ${ }^{191}$ Staff members outside this lead office rarely get involved in the matter; they do so only at the behest of the lead office when technical questions arise that require the expertise of these "outside" staff members. ${ }^{192}$ The group that generates the policy usually has to obtain ultimate approval for action from other offices, but the group has initial responsibility for collecting, organizing, and analyzing information, and the initial work goes a long way toward determining whether the agency will take action.

When an agency uses formal adjudication to set policy, staff input may come from an individual who testifies in the proceeding or writes a report on

187 See Cornelius M. Kerwin, Rulemaking: How Government AgEnCIES WRITE LAW AND MAKE POLICY 148-53 (2d ed. 1999); McGarity, supra note 87, at 8687; Seidenfeld, supra note 87 , at 528.

188 See McGarity, supra note 87 , at 89.

189 See Peter Strauss, Publication Rules in the Rulemaking Spectrum: Assuring Proper Respect for an Essential Element, 53 ADMIN. L. REV. 803, 804-05 (2001) (describing these guidance documents and discussing their importance as a tool for agencies to develop and announce policy).

190 The Administrative Procedures Act does not specifically require any procedure for informal adjudication, although its procedures for ancillary matters may apply to such adjudications. 5 U.S.C. $§ 555$ (2000); Pension Benefits Guar. Corp. v. LTV Corp., 496 U.S. 633,655 (1990) (stating that, absent due process requirements, the only procedures required for informal adjudication are the very basic ones set out in section 555 of the APA). Various statutes and agency rules, however, often provide for some opportunity for a party to present its case in most informal adjudications of any significance. See Michael Asimow, The Spreading Umbrella: Extending the APA's Adjudication Provisions to All Evidentiary Hearings Required by Statute, 56 ADMIN. L. REV. 1003, 1005-07 (2004).

191 Tom McGarity has dubbed this structure for generating rules and policies "the hierarchical model." McGarity, supra note 87, at 94-97 (describing a rulemaking process dominated by the lead program office).

192 McGarity, supra note 87, at 94. 
the issue to guide the ultimate decision maker how to come out. ${ }^{193}$ This individual usually comes from and reports to a particular office of the agency, but often he is singularly responsible for the formal input into the agency decision-making process. The ultimate policy decision usually is made by some sort of hearing officer, but such decisions tend closely to track the testimony in the case record.

\section{The Impact of Decision-making Structure and Procedure}

Group structure can ameliorate or exacerbate individual biases in propensity to act, depending on the nature and predilections of group members. One well documented phenomenon is social loafing, which causes individuals engaged in a group task to reduce their efforts below those they would exert were they acting alone. The explanation for this phenomenon boils down to individuals feeling that they can enjoy the benefits of group success without maximum personal exertion. ${ }^{194}$ Social loafing suggests that the group nature of agency staff input into agency policy would cause staff members to slough off and exhibit a propensity to refrain from acting even where action may be warranted. Group membership, however, can foster a sense of duty or obligation that can effectively override tendencies to engage in social loafing. If people believe that they can make a unique contribution to the group, they will not engage in social loafing, even if their individual contributions to the group will go unnoticed and unrewarded. ${ }^{195}$ And the make-up of most agency staff policymaking groups includes individuals with different areas of expertise and responsibility, suggesting that there may be sufficient means for determining each individual's contribution to the final product to minimize the affect of social loafing on staff members' propensities to act.

The need to achieve consensus of group members, which is also a requirement for staff action under most agency decision-making structures, can alter the likelihood that an agency will take action. If the members have different incentives with respect to agency action-for example, if credit or blame for action will go primarily to only a small subset of the group-then

193 The APA provides generally for trial type proceedings in adjudications subject to its formal procedures. For many programs, agencies provide trial type procedures by rule for adjudications of significance, even when their authorizing statutes do not trigger the APA's formal procedures. See Asimow, supra note 190, at 1008.

194 Bibb Latane, Kipling Williams \& Stephen Harkins, Many Hands Make Light the Work: The Causes and Consequences of Social Loafing, 37 J. PERSONALITY \& Soc. PSYCHOL. 822, 822-32 (1979).

195 Stephen Harkins \& Richard Petty, Effects of Task Difficulty and Task Uniqueness on Social Loafing, 43 J. PERSONALITY \& SOC. PSYCHOL. 1214, 1216 (1982). 
the need to achieve some consensus on whether to act might mollify individual action or omission biases, respectively. If, however, individuals within the group share similar feelings of responsibility for the action perhaps because they see themselves as part of a team responsible for the agency action at issue, and therefore share an irrationally positive penchant for action, then the phenomena of group polarization might magnify individual tendencies with respect to agency action. ${ }^{196}$ The likelihood of credit going to a small subset and of members holding different responsibility for group outcomes is likely to be greater in heterogeneous groups comprised of members from offices across the agency rather than a group comprised of members from a single office. Hence, the penchant for staff to push for a significant legislative rulemaking proposal that is generated by a pan-agency group is less likely to exhibit a bias toward action than either a proposal for more informal means of making policy, which often comes from within a single office within an agency, or advocacy by an individual staff member for a policy change within a particular adjudication.

In a limited set of circumstances conducive to groupthink, the group decision-making process can greatly enhance the likelihood for action where action is unwarranted (or even downright dangerous). "[G]roupthink involves a dynamic in which the desire to be part of the group and to share its values and prestige leads members to feel that the group is morally superior to its opponents, to stifle dissent, and to fail to subject the group consensus to critical considerations." 197 An example of a recent government decision that is hypothesized to have resulted from groupthink was the decision that Saddam Hussein had weapons of mass destruction ready for use in Iraq prior to the United States invasion in $2003 .{ }^{198}$ Groupthink is likely to occur when the group is facing a crisis situation, and the leader of the group is directive in nature. ${ }^{199}$ It is conjectured that groups that are more cohesive and homogeneous are at greater risk of engaging in groupthink, although

196 See Glenn S. Sanders \& Robert S. Baron, Is Social Comparison Irrelevant for Producing Choice Shifts?, 13 J. EXPERIMENTAL SOC. PSYCHOL. 303, 304 (1977); see also David Schkade, Cass R. Sunstein \& Reid Hastie, What Happened on Deliberation Day?, 95 CAL. L. REV. 915, 926-27 (2007).

197 Seidenfeld, supra note 87, at 541 (2002). For a full description of the groupthink phenomenon, and some possible examples of groupthink in government contexts, see generally IRVING JANIS, GROUPTHINK: PSYCHOLOGICAL STUDIES OF POLICY DECISIONS AND FIASCOES ( $2 d$ ed. 1982).

198 According to the 2004 Senate Select Committee's Report on the U.S. Intelligence Community's Prewar Intelligence Assessments on Iraq, the CIA "demonstrated several aspects of group think: examining few alternatives, selective gathering of information, pressure to conform within the group or withhold criticism, and collective rationalization." S. REP. No. 108-301, at 18-19 (2004).

199 See JANIS, supra note 197, at 249. 
laboratory experiments have failed to verify this. ${ }^{200}$ Thus, groups comprised of members from various offices within an agency are less likely to fall prey to groupthink and hence less likely to act when action is inappropriate than are groups from a single mission oriented office. ${ }^{201}$

\section{Two TALES OF AGENCY INACTION REVISITED}

Although the picture of what influences agency action is not tidy, the picture is nonetheless useful in evaluating whether judicial review warrants significant revamping because it unduly discourages agency action. I do not claim that judicial review has universally been good or bad in its influence on agency propensities to regulate. In fact, the untidiness of the picture about agency action suggests that whether active judicial review has a salutary rather than deleterious effect will depend on the particular regulatory program under consideration. But, at least the picture suggests that the almost unanimous condemnation of judicial review for its counterproductive slowing of agency action is overstated in its universality and insensitivity to the surrounding context of regulatory programs.

In this section, I revisit studies of two regulatory programs-FERCs deregulation of electric power and NHTSA's regulation of auto safety-that helped form the consensus that judicial review is to be condemned for its affect on agency action. By expanding the aperture through which agency action is viewed, I conclude that for both regulatory programs, judicial review has been unduly criticized - in one because slowing agency action may have provided significant benefits, and in the other because judicial review was merely a catalyst for other causes of detrimental avoidance of regulation rather than a root cause of the failure to regulate.

\section{A. FERC's Failure to Order Open Access to the Transmission Grid}

In the early 1990s, Richard Pierce predicted that the United States would experience dramatic power shortages over the coming years because judicial review would discourage FERC from issuing rules to help deregulate the electric power market. ${ }^{202}$ That market can be viewed as having three

200 See Marceline B. R. Kroon et al., Managing Group Decision Making Processes: Individual Versus Collective Accountability and Groupthink, 2 INT'L J. CONFLICT MGMT. 91, 92 (1991).

201 See Seidenfeld, supra note 87, at $544-45$.

202 Richard J. Pierce, Jr., The Unintended Effects of Judicial Review of Agency Rules: How Federal Courts Have Contributed to the Electricity Crisis of the 1990s, 43 ADMIN. L. REV. 7, 7 (1991). 
vertically related components - generation, transmission, and distribution. ${ }^{203}$ By the late 1980s, general consensus had developed that the structure of the electric power generation industry had changed so that traditional forms of regulation were no longer warranted. ${ }^{204}$ And even as early as the late 1970s, Congress passed legislation that began to break traditional vertically integrated monopoly power companies' stranglehold on power generation. ${ }^{205}$

The problem with deregulating only generation, however, is that electricity must be transmitted from the generator to the wholesale purchaser over a grid of transmission lines, and in many instances the owner of the lines between the generator and purchaser is a utility that competes in the power generation market. As a competitive market for generation developed, it became clear that the bottleneck for deregulation of the wholesale power market was the transmission grid, ${ }^{206}$ and FERC has authority to regulate that grid. ${ }^{207}$ Pierce argued, based on FERC's experience with its rules

203 See Stephen G. Breyer \& Paul W. MacAvoy, Energy Regulation by the FEDERAL POWER COMMISSION 90 (Brookings Inst. 1974).

204 See, e.g., PAUL L. JoSKOW \& RICHARD SCHMALENSEE, MARKETS FOR POWER: AN ANALYSIS OF ElECTRIC UTILITY DEREGUlation 45-58, 212-14 (1983) (contending however that, because of the nature of electric power and the structure of the existing industry, moving to a competitive market must be done carefully, and that the transition from regulated vertically integrated utilities to unbundled providers of generation, transmission, and distribution might warrant some continued regulation of power generation).

205 Public Utility Regulatory Policies Act of 1978, Pub. L. No. 95-617, § 210, 92 Stat. 3117,3144 (requiring utilities to purchase power from cogeneration and small hydro-electric power producers). Although PURPA was motivated by a desire to reduce oil consumption - encouraging cogeneration and small hydro production as cleaner alternatives to traditional utility-owned fossil fuel fired power generation-PURPA significantly cut into the regulated vertically integrated utilities market share for power generation. Jeffrey D. Watkiss \& Douglas W. Smith, The Energy Policy Act of 1992-A Watershed for Competition in the Wholesale Power Market, 10 YALE J. ON REG. 447, 453 (1993).

206 See Promoting Wholesale Competition Through Open Access Non-Discriminatory Transmission Services by Public Utilities, Recovery of Stranded Costs by Public Utilities and Transmitting Utilities, 60 Fed. Reg. 17,662 (proposed Apr. 7,1995 ) (stating that "[a]s entry into wholesale power generation markets increased, the ability of customers to gain access to the transmission services necessary to reach competing suppliers became increasingly important").

${ }^{207}$ Under the Federal Power Act, FERC has authority over all sales for resale of electric power. See 16 U.S.C. $\$ 824$ (2000). Until the courts affirmed FERC's Order 888, requiring all transmission line owners to provide open access tariffs for transmission of power, the extent of FERC's authority to issue a rule requiring utilities to wheel power generated by an entity other than the utility (that is allow others to transmit power over the utility-owned transmission facilities) was unclear. See Transmission Access Policy Study Group v. FERC, 225 F.3d 667, 688 (D.C. Cir. 2000) (holding that FERC had 
deregulating gas pipelines, that the agency's fear of being reversed on judicial review would discourage it from mandating transmission by rule, and thus would prevent the deregulation necessary for the power industry to continue to meet growing power demands in the United States. ${ }^{208}$

FERC was not likely to elevate the priority of transmission deregulation in response either to individual staff members' personal incentives or nonrational psychological influences. The problem of transmission bottlenecks was recognized even before deregulation, ${ }^{209}$ and their ability to interfere with a competitive generation industry was well known. Hence, it is unlikely that a staff member could claim any rule to order wheeling as his brainchild. In addition, the staff members in the FERC office responsible for ordering wheeling, which currently is the Office of Energy Markets and Reliability, includes engineers, ${ }^{210}$ and there is no professional engineering norm that would compel wheeling. Wheeling was compelled, if at all, by economists' desire to replace regulated electricity markets with competition. Nor does wheeling involve some "protected value" that some individuals simply would be unwilling to bargain away for other benefits. Wheeling potentially promised to save money, not lives or the environment. Finally, the politics of wheeling did not push strongly in one direction or the other. Vertically integrated private power companies generally were opposed to it, 211 but

authority under section 206 of the Federal Power Act to order involuntary wheeling); see also New York v. FERC, 535 U.S. 1, 28 (2002) (affirming Transmission Access Policy Study Group on the issue of FERC's authority to order open access of bundled sale of wheeling and retail power).

208 See Pierce, supra note 202, at 9-11.

209 In 1973, in Otter Tail Power Company v. United States, the Supreme Court held that a utility could violate the antitrust laws by refusing to open its transmission facility to potential competitors in the power market in order to stifle competition. 410 U.S. 366, 374-75 (1973). The Court noted that when the Federal Power Act was adopted in 1935, transmission was recognized as a necessary component to coordination of the power grid, but that Congress had left that coordination primarily up to voluntary transactions by power companies. Id. at 374.

$210 \mathrm{See}$ Federal Energy Regulatory Commission, http://www.ferc.gov/about/ offices/oemr.asp (last visited Mar. 2, 2009).

211 See Andrew Pollack, Shopping Around for Electric Power, N.Y. TIMES, Aug. 13, 1987, at D1 (stating "[u]tilities generally are not required to transmit power for other companies, and, with few exceptions, they have been hesitant to do so"). Many utilities were concerned that, if the market for retail power really became competitive, they would be unable to recoup their "stranded costs"-that is, their investment in power plants whose cost was too great to be recouped if power was sold at a competitive market rate. See William J. Baumol \& J. Gregory Sidak, Transmission Pricing and STRanded COSTS IN THE ELECTRIC POWER INDUSTRY 98-99 (1995) (asserting that allowing utilities to recoup stranded costs is the major barrier to deregulation, and showing how such costs could be included in a transmission rate and still promote efficiency). 
wheeling was consistent with the agenda of President Reagan for broad scale reliance on markets rather than government to discipline the provision of goods and services such as electricity, and a few power company executives favored open access to transmission lines, seeing such access as a necessary step for them to expand sales of the power they generated. Hence, one would suspect from my prior analysis that judicial review, rather than other incentives or bias-inducing circumstances, would have had a significant influence on FERC's decision whether to order wheeling of power.

If agency incentives and non-rational biases had any influence on FERC's propensity to order wheeling, they would have increased the inertia induced by judicial review. On the one hand, the potential benefit from acting would be maintenance of available electric power, which would be unlikely to attract either praise or blame. On the other hand, wheeling could increase demand for transmission and exacerbate coordination problems for already stressed transmission grids, and might even help trigger a large scale blackout, which would be a salient event for which FERC's engineers could expect some blame. In this context, action would avoid harm not attributable to the action - power shortages due to inability to transmit power where it is needed-but would also create the potential for harm that is attributable to the action - a possible blackout due to wheeling coordination problems. That is a classic scenario where the omission bias is likely to prevail over the action bias. In addition, ordering wheeling would have imposed costs on a politically powerful constituency of FERC - the incumbent power companies - to avoid uncertain future rate increases. This is a classic scenario in which loss aversion also discourages action. Thus, in this case, judicial review reinforced other factors that discouraged agency action.

It is therefore not surprising that Pierce was correct in his prediction that FERC would address the problem in a manner that would essentially avoid both judicial review and the extreme risks that a rule ordering wheeling would have generated. Instead of adopting a rule for the industry, FERC recognized that many owners of transmission facilities also were generators of power, and that they would need FERC rate approval to sell their power to customers that were not on their own distribution network. When these power companies sought approval to charge competitive market rates for selling power to entities other than their own distribution customers, FERC conditioned approval on these power companies having tariffs offering open access to their transmission grids. ${ }^{212}$ Power producers declined to challenge

212 See Joseph T. Kelliher, Pushing the Envelope: Development of Federal Electric Transmission Access Policy, 42 AM. U. L. REV. 543, 577 n. 149 (1992) (citing the remarks of FERC Chairman Martin L. Allday that FERC has and will continue to require utilities seeking market rate orders for wholesale power to have open access transmission tariffs); Watkiss \& Smith, supra note 205, at 458. 
the conditions put on these market rate orders because they did not want to delay let alone risk their ability to sell the power they generated. But, the company-by-company opening of the transmission grid was slow and did not open up the transmission grid in any comprehensive fashion. Therefore, it did not allow retail deregulation to proceed on a large scale. Deregulation proceeded very deliberatively, with the inclusion of a single utility's transmission lines in an open grid, allowing the utility to develop a transmission tariff addressing how to price transmission, as well as insuring that the wheeling requirement would not interfere with system reliability or the utility's ability to deliver power to its own customers. ${ }^{213}$ But at the same time the power shortages that Pierce predicted did not materialize, and the power industry generally operated smoothly.

In 1992 Congress passed the Energy Policy Act, which clarified FERC's power to order an owner of a transmission facility to wheel power, but only on a case-by-case basis after FERC made particular findings that the order would maintain reliability and be in the public interest. Nonetheless, the Act sent a strong message to FERC to order wheeling. ${ }^{214}$ In 1996, FERC proceeded to order wheeling universally, instead of on the case-by-case basis it had used as a condition for its market rate orders or that the EPA of 1992 had authorized. Relying on its authority to prevent discriminatory practices in the provision of wholesale electricity services, FERC adopted a rule ordering all transmission line owners to file tariffs to open their lines to transmission of power generated by other companies. ${ }^{215}$ The D.C. Circuit affirmed this rule as being within FERC's authority and as passing the arbitrary and capricious standard of review, ${ }^{216}$ and efforts to create competitive wholesale and retail electricity markets quickly accelerated. The workings of the electric power industry, however, are intricate in part because electric power cannot be stored easily (unlike natural gas) and in part because electrons do not flow over directed paths but rather spread over the power grid in currents that are inversely proportional to the resistance of the various paths open to

213 Pricing and reliability remain problematic even fifteen years after Pierce first wrote advocating a rule requiring wheeling and more than ten years after FERC essentially adopted such a rule. See Report of the Electricity Regulation Committee, 28 ENERGY L.J. 267, 277-78 (2007).

${ }^{214}$ Energy Policy Act of $1992 \S 721,16$ U.S.C. $\S 824 j$ (a) (2000) (amending FPA $\S 211(\mathrm{a}))$.

215 See Promoting Wholesale Competition Through Open Access Nondiscriminatory Transmission Services by Public Utilities, Recovery of Stranded Costs by Public Utilities and Transmitting Utilities, Order No. 888, 61 Fed. Reg. 21,540 (1996) (stating in summary that the rule requires public utilities that own transmission facilities to make them available by filing non-discriminatory open access tariffs).

216 Transmission Access Policy Study Group v. FERC, 225 F.3d 667, 687, 689 (D.C. Cir. 2000). 
them. ${ }^{217}$ These fundamental attributes of electricity, it turns out, mandate that deregulatory efforts be carefully structured and implemented only when the transmission facilities of the various power companies in a regional transmission grid are well coordinated or the likely result will be regulatory catastrophes rather than triumphs. Even in 1996, when FERC issued Order 888 , at a time when the limitations of deregulating the power market were better understood, the rule requiring utilities to wheel power contributed to some electric power fiascos throughout the United States.

California's program to deregulate retail power illustrates this point. Because of the way that California implemented its program, large companies like Enron could manipulate the supply of power generation to create artificial shortages in California's wholesale market, and artificially raise the price for power transmission within the market. 218 Although California's deregulatory scheme had many flaws, susceptibility of the wholesale market to manipulation by companies that did not have market power, in the traditional sense, over generation or transmission was not appreciated when FERC ordered wheeling of power in 1996, let alone in the late 1980s when Pierce advocated mandating wheeling. In a recent article again advocating deregulation of electricity markets, Pierce acknowledges that his initial call for deregulation may have underestimated the problems facing deregulation when he first advocated it in the late 1980s.219 In addition, he notes that nodal pricing, a mechanism necessary to guard against abuses and to provide accurate price signals for transmission, was first developed in 1993.220 In fact, Pierce blames the deregulation fiasco in California in part on the state's failure to use this node pricing system.221 Implicitly, Pierce thereby concedes that this fiasco might have occurred on a

${ }^{217}$ Richard J. Pierce, Jr., How Will the California Debacle Affect Energy Deregulation?, 54 ADMIN. L. REV. 389, 395-96 (2002).

218 Some of the errors made by the California attempt to provide retail competition included imposing price caps that distribution companies could pay on wholesale purchases of power, prohibiting distribution companies from entering into long-term contracts for power, and using a zone method for pricing transmission that allowed manipulation of the rate paid for transmission. See Richard J. Pierce, Jr., Completing the Process of Restructuring the Electricity Market, 40 WAKE FOREST L. REV. 451, 473-77 (2005) [hereinafter Pierce, Completing the Process]; see also Pierce, supra note 217, at 394-401 (describing factors-some extraneous, some part of the system California set up that allowed individual entities to act strategically to withhold power-that contributed to the California power crisis).

219 Pierce, Completing the Process, supra note 218, at 464-66 (2005).

220 According to Pierce, the nodal pricing system was developed by William Hogan as "the last essential element of a viable plan to restructure the United States electricity market." Id. at 468.

${ }^{221}$ Id. at $473-74$. 
much wider basis had FERC ordered wheeling in the late 1980s, before the node pricing system was developed. ${ }^{222}$

A major power blackout in the Ohio Valley and surrounding states, as well as Ontario, illustrated another problem with deregulation. The potential for local power outages or voltage reductions in any particular distributor's service area significantly decreases with the interconnection of the power grid because interconnection allows power to be delivered over alternative paths if one line fails. But, interconnection increases the potential for wider blackouts. ${ }^{223}$ If various companies' transmission facilities are not adequately integrated and power flows over them are not coordinated, excess demands on one company's lines can cause the shut down of those lines, which in turn forces more power to be transmitted over other lines on the grid. This in turn can cause those other lines to overload and shut down. This scenario of cascading overloads is essentially what happened during the power outage of 2003. 224 The prospects of transmission line overloads, while not directly caused by FERC's mandated wheeling in Order 888, is exacerbated by that Order because requiring wheeling at the same cost the utility pays to use its own transmission lines leaves little incentive for a power company to build its own transmission facilities. Instead, it can rely on those of other power companies instead, thereby avoiding the risk that it will fail to recoup its investment in such facilities. ${ }^{225}$ But if all power companies rely on others to build transmission lines, there will be a shortage of transmission facilities, which is precisely what has developed in the United States. ${ }^{226}$ Again, Pierce's recent article concedes that this is a current problem because the

222 By arguing that California's fiasco was caused in large part by that state using a zone rather than a nodal system for pricing transmission, id. at 473-74, and noting that the nodal system was not proposed until $1993, i d$. at 468 , Pierce essentially concedes that there was insufficient knowledge about how to price transmission in the late 1980s to effectively implement open transmission access.

223 See Steven J. Eagle, Securing a Reliable Electricity Grid: A New Era in Transmission Siting Regulation?, 73 TENN. L. REV. 1, 12 (2005) (stating that due to grid interconnection "problems in bottleneck [transmission] areas can have wide-ranging effects").

224 Technically, the 2003 blackout was caused by the threat of overloads, which caused the system to trigger automatic power generator disconnects, which then caused cascading voltage drops. See Damon P. Frank, The Great Lakes Blackout and Electricity Provider Liability, 10 LAW \& BUS. R. AM. 235, 235-36 (2004) (summarizing U.S. DEPARTMENT OF ENERGY, TIMELINE 2003, AUGUST 14, 2003, available at http://energy.gov/about/timeline2003.htm.).

225 See Eagle, supra note 223, at 5.

226 See Richard J. Pierce, Jr., Environmental Regulation, Energy, and Market Entry, 15 Duke EnVtl. L. \& POL'Y F. 167, 176-80 (2004); Pierce, Completing the Process, supra note 218 , at 469,495 . 
United States generally faces a shortage of transmission lines, and he states that FERC will have to find a way to encourage significant investment in transmission capacity. 227

Finally, by forcing a power producer with transmission facilities to make those facilities available to competitors on the same basis as it provides transmission for power it generates, FERC may render the producer unable to deliver power to its native retail customers when transmission capacity is overtaxed. While eliminating loopholes in open access that a utility might use to favor sales of power it generates is important, requiring utilities to provide facilities for competitors at a time when doing so will require that they interrupt service to their retail customers not only threatens to disrupt reliance on power companies to deliver electricity to end users on demand, it seriously undercuts any incentive a utility may otherwise have to maintain and increase its transmission capacity. Thus, when Northern States Power faced a FERC order to wheel power that would have displaced power it provided to its own retail customers, the reviewing court sensibly held that FERC exceeded its authority. 228

The gist of this story is that, as Pierce predicted, in the late 1980s judicial review probably played an important role in dissuading FERC from issuing a rule ordering transmission access until 1996, when the political lay of the land changed sufficiently to motivate FERC to issue Order 888 . But, judicial review deterred rulemaking in part because of FERC's uncertainties about how such a rule would affect the electrical power system in the United States. Far from being a factor that prevented the agency from adopting a rule that would provide clear benefits, judicial review in fact delayed the rule until FERC gained knowledge that helped FERC implement open transmission access more successfully than would have been the case a decade earlier. Its policy of case-by-case mandatory wheeling provided experience that most likely helped FERC avoid exposing the country to greater risk of market failures and power outages such as occurred in California in 2000 and in the Upper Midwest in $2003 .{ }^{229}$ For example, the

227 Pierce, Completing the Process, supra note 218 , at $482-83$. Under the current system of open access to transmission facilities, companies have a disincentive to build power lines because they cannot charge more than a regulated rate for access, but unlike the days of traditional rate regulation, they are not assured that they will be able to recoup their reasonable investment. Pierce contends that granting FERC authority to preempt state regulators by approving transmission lines that the state regulators oppose would solve the transmission capacity shortage, $i d$. at 493 , but he does not explain how this will give companies an incentive to build power lines.

228 Northern States Power Co. v. FERC, 176 F.3d 1090, 1096 (8th Cir. 1999).

${ }^{229}$ See Jim Rossi, Redeeming Judicial Review: The Hard Look Doctrine and Federal Regulatory Efforts to Restructure the Electric Utility Industry, 1994 WIS. L REV. 
PJM transmission grid's use of nodal pricing that Pierce claims is so successful would not have been possible in the late 1980s. One cannot prove, of course, that had FERC adopted a rule mandating wheeling in the late 1980s that more market failures or problems coordinating transmission grids would have occurred. The lack of an energy shortage from the late $1980 \mathrm{~s}$ through 1996, however, and the troubles that have plagued the development of a competitive wholesale market from 1996 to the present suggest that the delay in rulemaking was not necessarily a bad thing, let alone the catastrophe that Pierce initially predicted.

\section{B. NHTSA's Retreat from Auto Safety Standards}

If FERC's mandate of wheeling of electric power is an example where judicial review does not receive adequate credit for helping, at least temporarily, to stave off blackouts and electricity shortages, then the National Highway Traffic Safety Administration's auto safety standards is an example where judicial review may bear too much blame for causing the agency to abandon a program that scholars generally acknowledge to have held the promise to save thousands of lives.

\section{Mashaw and Harfst's Story of NHTSA}

Congress passed The National Traffic and Motor Vehicle Safety Act in 1966 virtually unanimously. ${ }^{230}$ The Act, based on what Jerry Mashaw and David Harfst label the "New Science of Accidents," 231 created a new agency, the National Traffic Safety Administration, ${ }^{232}$ and demanded that the agency regulate aggressively to require automobile manufacturers to build cars that would help avoid accidents and protect their occupants from injury in case of accidents. ${ }^{233}$ According to Mashaw and Harfst, the demand for such safety regulation was universally shared and promised significant benefits to the

763,805 (stating that "[t]hrough concrete cases, FERC can best decide which policies are suited to current technological, regulatory, and market conditions").

230112 CONG. REC. 21,382-83 (1966).

231 Jerry L. Mashaw \& David L. Harfst, The Struggle for Auto SafeTy 1 (Harvard University Press 1990).

232 The Highway Safety Act of 1966 created the National Traffic Safety Agency. Pub. L. No. 89-563, $\S 115,80$ Stat. 718, 727 (1966). The agency's name was later changed to the National Highway Traffic Safety Administration. Pub. L. 91-605, $\S 202$ (a), 84 Stat. 1713, 1739 (1970).

233 Pub. L. No. $89-563 \S 103,80$ Stat. 718,719 (1966) (codified at 15 U.S.C. $\S 1381$ (1966) (repealed 1994)). 
American public; even the industry did not fight the Act's call for aggressive safety regulation with any zeal. 234

The Act called for adoption of initial auto safety regulations based on existing standards over a very short time period, ${ }^{235}$ which essentially forced the head of NHSTA, Dr. William Haddon, to take a pragmatic initial approach of adopting the actual existing industry standards. Dr. Haddon's preference for certain scientific support caused the agency to further weaken even these standards. ${ }^{236}$ This initial non-aggressive regulation angered some of the scientists in the agency who felt that NHTSA should proceed more quickly to force the development of new safety technologies. Thus, the head of the agency rulemaking team, William Steiglitz, who had virtually created the science of auto safety in the 1960 s, resigned because of disappointment with the progress of adoption of aggressive safety standards. ${ }^{237}$ Shortly after the promulgation of the initial standards, the agency proposed a second set of standards that reflected its own safety initiatives, but did not depend on development of revolutionary technology. Nonetheless, in response, the auto industry began to complain about the imposition of even these standards. ${ }^{238}$

The agency acted slowly and deliberatively until 1969. At that time, it proposed passive restraint rules to protect the occupants of an automobile from the "second collision" that occurs after a vehicle crashes when the occupants crash into the inside walls of the car. ${ }^{239}$ As the statute envisioned, ${ }^{240}$ the proposed rule relied on technology that had not yet been developed. Mashaw and Harfst see this proposed rule, and some others that

${ }^{234}$ MASHAW \& HARFST, supra note 231, at 60; see also HOWARD M. BUNCH \& MiCHAEl KUBACKI, HIGHWAY SAFETY RESEARCH INSTITUTE, UNIVERSITY OF MiCHIGAN, AN ANALYSIS OF INDUSTRY RESPONSES TO FEDERAL REgUlations IN SAFETY REQUIREMENTS FOR NEW AUTOMOBILES 10 (1977), available at http://deepblue.lib.umich.edu/handle/2027.42/632.

235 Pub. L. No. 89-563, § 103(h), 80 Stat. 718, 720 (1966).

236 MASHAW \& HARFST, supra note 231, at 75.

237 See id. at 72; MARTIN Albaum, SAFETy Sells: MARKET ForCES AND REgUlation IN THE DEVELOPMENT OF AIRBAGS 19 (2005), available at http://safetysells.org/chapter2.pdf; Philip M. Boffey, Nader and the Scientists: A Call for Responsibility, 171 SCIENCE 549, 550 (1971).

238 See BUNCH \& KUBACKI, supra note 234, at 14 (stating that "[m]ost of [the auto industry's] critical comments were directed toward a need to have a longer period to prepare for implementation, or toward further assessing the benefits of the standard").

${ }^{239}$ See Inflatable Occupant Restraint Systems, 34 Fed. Reg. 11,148 (proposed July $2,1969)$.

${ }^{240}$ See Pub. L. No. 89-563, § 106, 80 Stat. 718, 721 (1966) (authorizing the agency to conduct research in order to set standards). 
followed, as the agency finally attempting to fulfill the mandate set out by the Motor Vehicle Safety Act. 241

From their perspective, however, the fulfillment of the promise of the Act was stymied by judicial reversals of agency rules as arbitrary and capricious, starting in 1972 with the Sixth Circuit reversal of NHTSA's passive restraint rule. ${ }^{242}$ This was followed by reversals of other rules by other courts. According to Mashaw and Harfst, judges imposed virtually impossible standards on the agency. ${ }^{243}$ This discouraged the agency and especially Haddon, who was always careful to avoid judicial reversal. ${ }^{244}$

In 1974, after Haddon resigned as agency head, Congress considered amendments to the Act to give NHTSA greater authority to adopt more aggressive occupant protection rules. By this point in time, the automobile industry was better organized to oppose efforts to regulate auto safety, and congressional efforts to get NHTSA to adopt technology forcing standards failed. ${ }^{245}$ As a result, NHTSA sought and Congress passed instead a statute that relied on recalls of defective automobiles even though there was no evidence that recalls would have any effect on automobile safety. ${ }^{246}$ The agency looked away from its safety standard program and instead focused on its recall authority.

\section{A Revisionist Story of NHTSA}

NHTSA was created during a unique time of trust in government and technology. The American public was fascinated by the success of American efforts in space exploration, and the country was optimistic about its economic future. This coincidence of circumstances allowed strong advocates of the science of accidents both in Congress and in existing administrative agencies to get legislation passed aimed at using technology to reduce the incidence of accidents due to human limitations, and to create crash-worthy automobiles. At its inception in 1966, the makeup of NHTSA and the political atmosphere that brought it into being favored aggressive

241 MASHAW \& HARFST, supra note 231, at 87.

242 Chrysler Corp. v. Dep't of Transp., 472 F.2d 659, 681 (6th Cir. 1972).

243 MASHAW \& HARFST, supra note 231, at 91-95.

244 See id. at 95; see also Motor Vehicle Safety Standards: Hearings before the S. Comm. on Commerce, 90th Cong. 235 (1967).

245 See MASHAW \& HARFST, supra note 231, at 117-18; see also BUNCH \& KUBACKI, supra note 234, at 55 (noting that by 1975, the economic environment and concern about conserving gasoline had changed so that auto industry criticism of proposed rules became more emphatic).

246 Motor Vehicle and Schoolbus Safety Amendments of 1974, Pub. L. No. 93-492, $\S 152,88$ Stat. $1470,1470-71$ (1974). 
regulation to force manufacturers to build safer automobiles. ${ }^{247}$ The personal background and to some extent the prescient understanding of NHTSA's first head, William Haddon, who appreciated the need for the agency to adopt its initial rules very quickly and who did not want the agency to proceed with regulation without essentially irrefutable scientific evidence of the feasibility and prudence of safety standards, ${ }^{248}$ prevented the agency from being overzealous in its initial efforts to impose auto safety standards. But, after quickly adopting initial standards, albeit not very aggressive ones, in 1970 the agency started to implement what it saw as its mandate to force automakers to develop new, potentially costly auto safety technology. 249

The nature of the agency staff and its political support in 1970, however, put the agency well ahead of the American public in pushing for technological solutions to auto safety. Significant incentives and non-rational influences encouraged the agency head and staff to adopt strong and sweeping standards to implement auto safety. Haddon and his rulemaking team, who were safety scientists and engineers with stellar technical reputations in their fields, ${ }^{250}$ stood to gain further recognition in their professions by getting the agency to adopt significant safety standards. In short, "NHTSA's engineers [were] most qualified and interested in writing vehicle safety standards," 251 and that is what they did. While Haddon was a cautious administrator, he supported his staff's emphasis on safety standards that were proposed based solely on engineering feasibility. Essentially, by proposing standards based on engineering considerations, the agency internally bestowed respect and prestige on those in the agency who promoted its aggressive regulatory agenda, and thereby encouraged the members of its rulemaking team to ignore economic and political considerations. Simultaneously, NHTSA staff members saw their role as being responsible to make sure that automobiles were safer regardless of human error or limitations, ${ }^{252}$ and this perceived responsibility biased the agency toward taking action to make cars safer without considering cost or

247 S. REP. NO. 89-1301, at 2719 (1966).

248 MASHAW \& HARFST, supra note 231, at 75.

${ }^{249}$ See, e.g., Airbrake Line Couplers, 35 Fed. Reg. 13,465 (Aug. 22, 1970); Accelerator Control System, 35 Fed. Reg. 15,241 (Sept. 30, 1970); Occupant Crash Protection in Passenger Cars, Multipurpose Passenger Vehicles, Trucks, and Buses, 35 Fed. Reg. 16,927 (Nov. 3, 1970).

250 See Charles Pruitt, People Doing What They Do Best: The Professional Engineers and NHTSA, 39 PUB. ADMIN. REV. 363, 365-66 (1979) (noting that the numerical dominance of engineers at NHTSA resulted in a technical and mechanical research "independence" from the auto industry).

251 Id. at 365.

252 See id. at 364. 
the likely reaction of the American public to intervention into "the everyday lives and decisions of the automobile consumer."253 The fact that staff members saw themselves as responsible for the ultimate protected valuelife-likely magnified their bias toward action stemming from perceptions of responsibility for auto safety. In short, the incentives and non-rational influences on agency action unduly promoted agency action.

In essence, NHTSA got ahead of the American public on the issue of auto safety. The agency did not factor into its cost-benefit analysis the extent to which Americans valued freedom to drive as they wish and to spend their discretionary money on luxury appointments in cars rather than safety features. This explains how the agency made the blatant error of requiring ignition interlocks to prevent drivers from starting their cars without fastening seatbelts, a rule that generated so much outrage that Congress overruled it within two years, and in doing so amended the Motor Vehicle Safety Act in 1974 to prohibit the agency from adopting any standard involving any disabling of a vehicle such as the ignition interlock. ${ }^{254}$

In addition, the unique make up of the congressional oversight committee and the euphoric trust in government of the mid-1960s may have given the agency a false sense that it could count on political support for an aggressive auto safety program. By 1972, the politics of auto safety was quickly changing. Vietnam and Watergate made the public less trusting of government. ${ }^{255}$ High inflation rates made consumers more cost conscious and less willing to pay extra for features they did not want in a car. ${ }^{256}$ Gas shortages due to the Arab oil embargo of 1973 made the cars of the emerging Japanese auto industry more attractive, ${ }^{257}$ threatening competition with the United States big three automakers and making those manufacturers more leery of having to comply with technology-forcing safety standards.

Despite Mashaw and Harfst's intimation to the contrary, judicial reversals of agency rules did not impose impossible burdens on NHTSA. In

253 Id. at 366.

254 Pub. L. No. 93-492 § 103(2)(A), 88 Stat. 1470, 1477 (1974).

255 Loren A. Smith, Judicialization: The Twilight of Administrative Law, 1985 DUKE L.J. 427, 440 (1985).

256 Gallup polls indicated that by 1973 the public was far and away most concerned about the rising cost of living $(89 \%)$, followed by trust in government $(17 \%)$, and corruption and Watergate (14\%). Frederick Schauer, Foreward: The Court's Agendaand the Nation's, 120 HARV. L. REV. 4, 61 n.216 (2006).

257 Jeffrey N. Gordon, The Shaping Force of Corporate Law in the New Economic Order, 31 U. RICH. L. REV. 1473, 1481 (1997); Katherine Langley, Comment, The Fortress Faces East: Protecting Europe's Auto Industry, 1991 WIS. L. REV. 1043, 1058 n.77; Alan Greenspan, Chairman, Fed. Reserve, Energy: Remarks Before the Center for Strategic \& International Studies, Washington, D.C., (Apr. 27, 2004), available at http://www.federalreserve.gov/boarddocs/speeches/2004/20040427/default.htm. 
fact, in response to the Sixth Circuit's ruling that NHTSA had failed to specify test dummy structures adequately and sufficiently objectively, NHTSA proposed a specification for test dummies within nine months of that court decision. ${ }^{258}$ Judicial review of the aggressive proposed rules delayed adoption of those rules to a point where, because of distrust of the agency's aggressive agenda and the changed political climate, the agency no longer enjoyed the support of Congress. Political controversy, not the inability to specify test dummies, prevented the agency from adopting an airbags standard for over ten years after the agency was ready to specify dummies' structure sufficiently to satisfy the Sixth Circuit's standard. Focus on recall provisions, which had been in the statute to begin with ${ }^{259}$ but was not the program under which the agency initially sought to proceed, was mandated by congressional overseers, ${ }^{260}$ not by the agency in response to judicial review.

In short, judicial review slowed NHTSA's aggressive regulation down, and allowed auto manufacturers and the American public to influence Congress virtually to scrap the agency safety standard program. In terms of usual cost-benefit analysis, replacing the program with recalls may have been a mistake, but it was not the fault of judicial review. And if one counts the alienation of the American public as a cost, it is debatable whether NHTSA's technology-forcing safety standard program was cost-justified. ${ }^{261}$

\section{CONCLUSION}

In many instances, an agency has to decide whether to devote its resources to address a problem that is within its statutory authority. Many scholars of "hard look" judicial review of agency regulation have asserted that such review raises the costs to agencies of regulating and thereby discourages agencies from regulating when they should. That assertion, however, warrants a closer look in light of a fuller understanding of the

\footnotetext{
25838 Fed. Reg. 20,451 (Aug. 1, 1973).

259 Pub. L. No. 89-563 § 111 (a), 80 Stat. 718, 724 (1966).

260 Pub. L. No. 93-492 § 154, 88 Stat. 1470, 1472 (1974).
}

261 See Pruitt, supra note 250, at 366. To be fair to Mashaw and Harfst, they do not lay all the blame for NHTSA's abandonment of its automobile safety standards program at the feet of reviewing courts. They recognize that such review came just before the political winds seemed to change, which they consider an unfortunate circumstance. MASHAW \& HARFST, supra note 231, at 92, 134-40. But they do make clear that they believe that judicial review was being carried out in an inappropriate fashion and that it had a great influence on the agency's willingness to adopt stringent safety standards. Id. at 92 . 
rational incentives and non-rational influences on those within agencies to prefer taking action versus doing nothing.

The costs and benefits of regulation to society differ greatly from the costs and benefits that the agency experiences when it regulates. For this reason, evaluating the effect of judicial review on decisions whether to regulate must take into account all the influences on this decision. It may be that the impact of judicial review is swamped by that of other factors. Even if judicial review does significantly discourage regulation, it is possible that such discouragement counterbalances other influences that might cause agencies to be unduly prone to act when regulation is not warranted. After reviewing the influences on agency action, it appears that whether judicial review's discouragement of agency action is appropriate depends on the precise context of the environment in which the decision whether to regulate arises.

The complexity of the effect of judicial review on agency decisions to act is illustrated by two notorious agency decisions to forego or abandon regulation, for which judicial review has been blamed for inappropriately discouraging agency action. Applying an analysis of the incentives for agency action to these two decisions demonstrates that both the importance of judicial review and the propriety of its impact on the agency decisions not to regulate are much more nuanced than the simple picture of blame that critics of judicial review have attempted to draw. 
